\title{
Genetic Approaches to Hypothalamic-Pituitary-Adrenal Axis Regulation
}

\author{
Melinda G Arnett ${ }^{\star, 1,2}$, Lisa M Muglia ${ }^{1}$, Gloria Laryea ${ }^{1,3}$ and Louis $\mathrm{J} \mathrm{Muglia}^{1,2}$ \\ ${ }^{1}$ Cincinnati Children's Hospital Medical Center, Center for Prevention of Preterm Birth, Perinatal Institute, Cincinnati, OH, USA; \\ ${ }^{2}$ Department of Pediatrics, University of Cincinnati College of Medicine, Cincinnati, OH, USA; ${ }^{3}$ Neuroscience Graduate \\ Program Vanderbilt University, Nashville, TN, USA
}

\begin{abstract}
The normal function of the hypothalamic-pituitary-adrenal (HPA) axis, and resultant glucocorticoid (GC) secretion, is essential for human health. Disruption of GC regulation is associated with pathologic, psychological, and physiological disease states such as depression, post-traumatic stress disorder, hypertension, diabetes, and osteopenia, among others. As such, understanding the mechanisms by which HPA output is tightly regulated in its responses to environmental stressors and circadian cues has been an active area of investigation for decades. Over the last 20 years, however, advances in gene targeting and genome modification in rodent models have allowed the detailed dissection of roles for key molecular mediators and brain regions responsible for this control in vivo to emerge. Here, we summarize work done to elucidate the function of critical neuropeptide systems, GC-signaling targets, and inflammation-associated pathways in HPA axis regulation and behavior, and highlight areas for future investigation.

Neuropsychopharmacology Reviews (2016) 41, 245-260; doi:10.1038/npp.20I5.2I5; published online 12 August 2015
\end{abstract}

\section{INTRODUCTION}

It has been known since the mid 1800s that loss of adrenal function in primary adrenal disorders results in mortality (Addison's disease), if untreated. Excessive adrenal function arising from pituitary or adrenal tumors also leads to substantial morbidities such as obesity, muscle weakness, glucose intolerance, and mood disorders (Cushing's Syndrome) (Wilson, 1992). The relation of adrenal responses to stress-with stress reflecting deviations from normal organismal physiological or psychological set points-demonstrated more common, equally important, functions for the hypothalamic-pituitary-adrenal (HPA) axis in the general adaptation syndrome (Selye, 1936). Abundant research over the last half century has further recognized the strong association of dysregulation of HPA axis activity with psychiatric disorders such as PTSD, depression, and anxiety disorders (Fries et al, 2014; Kinlein et al, 2015; Naughton et al, 2014). These consequences of altered HPA function arise as a result of both altered glucocorticoid (GC) secretion affecting CNS and peripheral targets, and dysregulation of neuropeptides involved in mediating the stress response through their

${ }^{*}$ Correspondence: Dr MG Arnett, Cincinnati Children's Hospital Medical Center, Center for Prevention of Preterm Birth, Perinatal Institute, 3333 Burnet Avenue, MLC 7009, Attention Melinda Arnett, Cincinnati, OH 45229, USA, Tel: +1 513803 8040, Fax: +1 513803 5009, E-mail: melinda.arnett@cchmc.org

Received 3 March 2015; revised 9 July 2015; accepted 9 July 2015; accepted article preview online 20 July 2015 actions on limbic and other brain regions. Understanding the precise regulation of adrenal activity by $\mathrm{CNS}$ and peripheral signals and optimally, matching adrenal response duration and amplitude with stimulus, or stressor, intensity, has been a focal point for neuroscientists and endocrinologists. The ability to unravel the specific neural circuits involved in HPA responses and behavioral outputs has been accelerated by the application of transgenic and gene targeting methods in rodent models, which allow detailed measurement of physiological and behavioral actions in vivo, with specificity and manipulability not often achieved by other approaches. In this review, we will summarize the findings from gene targeting studies in the CNS, pituitary, and peripheral sites, which critically impact HPA axis/GC regulation and concomitant behavioral alterations.

The HPA axis, with the production of GCs, is a classic endocrine circuit that is regulated primarily, though not exclusively, through negative feedback mechanisms. When an organism experiences stress, parvocellular neurons of the paraventricular nucleus (PVN) of the hypothalamus secrete corticotropin-releasing hormone $(\mathrm{CRH})$ and arginine vasopressin (AVP) into the hypophysial portal vessels that reach the anterior pituitary. CRH and AVP actions on pituitary corticotrophs, through their associated G protein-coupled receptors, stimulate the release of adrenocorticotrophic hormone (ACTH). Systemically-released ACTH acts on the adrenal cortex to induce GC synthesis and secretion from the zona fasciculata. GCs, cortisol in humans and corticosterone 
(cort) in rodents, initiate physiological and behavioral responses through ubiquitously expressed GC receptors (GRs). Two GC-activated receptors, the type I mineralocorticoid receptors (MRs, high affinity) and type II GC receptors (GRs, low affinity, activated when cort concentrations are high), mediate the effects of GCs. GR and MR are expressed in different patterns in the brain: GR is nearly ubiquitous, while MR is restricted to the hippocampus (HC), central nucleus of the amygdala (CeA), and lateral and medial septum (LS and MS) (Kolber et al, 2008). GRs mediate negative feedback of the HPA axis by inhibiting secretion of PVN CRH and AVP, as well as anterior pituitary ACTH, preventing excessive release of GCs (Figure 1). Actions of GCs at other CNS extrahypothalamic sites have more subtle modulatory actions. For example, GC action on the HC may serve to inhibit HPA axis activity, while GC action on the amygdala or bed nucleus of the stria terminalis (BnST) activates HPA activity (Herman et al, 2012). Under conditions of persistent stress exposure, HPA axis activity may become dysregulated and result in impaired GC signaling (Herman, 2013; Bamberger et al, 1996; McEwen and Stellar, 1993). Inappropriate regulation of the stress response, in the context of chronic stress, has been linked to a wide array of pathologies including autoimmune disease, hypertension, and affective disorders. Rodent models have been utilized to establish a causal relationship between disrupted GC signaling in specific brain regions with altered stress responses. In the following sections, we will summarize the key findings from these studies, focusing on the receptors and neuroendocrine molecules found to be critical to GC signaling: GC receptors, $\mathrm{CRH}$ and its receptors, MRs, vasopressin, oxytocin $(\mathrm{OT})$, pro-opiomelanocortin (POMC, the precursor to ACTH), ACTH and inflammatory cytokines, which alter the HPA axis. We will conclude with a review of ongoing translational studies, as well as gaps in knowledge that would benefit from future study.

\section{GENETIC ALTERATIONS}

\section{GC Receptors}

GCs exert their actions via MR, to be discussed later, as well as GR, which binds GCs primarily post-stress, when GC levels are high. Both activation and negative feedback regulation of the HPA axis are modulated by GR in several brain regions involved in stress activation of the HPA axis. Because global congenital deletion of GR results in death during the first few hours of life due to impaired lung development and atelectasis, various lines of CNS GR knockouts, over-expressors and mutants with reduced or altered function, have been generated to characterize the different roles of GR in specific regions of the CNS which are known to be involved in stress circuitry. These models include: forebrain-specific deletion of GR (FBGR KO); deletion of GR in PVN CRH producing neurons $\left(G R^{f l o x /+}\right.$; Sim 1 Cre) (Sim1Cre-GRe2A); POMC/Cre-mediated deletion of GR in the pituitary; deletion of GR in dopaminoceptive

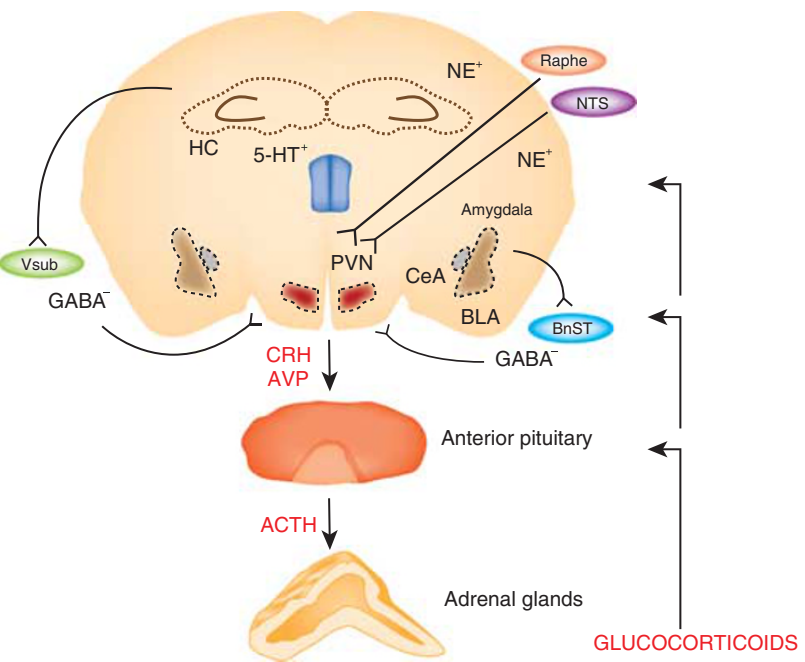

Figure 1. HPA axis regulation by the endocrine and central nervous systems neurons in the central nervous system (CNS) can affect HPA axis activity by regulating $\mathrm{CRH}$ secretion in the PVN. Extrahypothalamic regions that influence the HPA axis through neuropeptide secretion include the bed nucleus of the stria terminalis (BnST), dorsal raphe nucleus (raphe), nucleus of the solitary tract (NTS), and the ventral subiculum (Vsub). The neurotransmitters from these regions can have an inhibitory $(\gamma$ aminobutyric acid [GABA]) or excitatory (norepinephrine [NE], and serotonin [5-HT]) effect on the PVN. +=excites, $-=$ inhibits.

neurons of the nucleus accumbens (NAc) $\left(\mathrm{GR}^{\mathrm{D} 1 \mathrm{Cre}}\right.$ mice); lentiviral-Cre-mediated deletion of GR in the mouse CeA (CeAGRKO); GR deletion in the PFC of rats (ilPFC and plPFC GR knockdown); and adenoviral-mediated deletion of GR in the dorsal raphe nucleus (DRNGRKO). Because GR is expressed throughout the brain, models of GR disruption in specific brain regions help to uncover the multiple roles of GR in regulation of the HPA axis.

Forebrain GR deletion. The forebrain is composed of cortical and limbic brain regions, which are critical for processing instincts and emotions. Disruption of stress signaling in this circuitry is thought to underlie affective disorders such as anxiety and depression. Mice with a specific deletion of GR in the forebrain were generated to examine the role of forebrain GR in regulating HPA axis activity. Mice with loxp sites flanking the exon 1C-2 region of the GR allele containing promoter elements, translation start site, and the transcriptional activation domain were mated with $\mathrm{CamKII} \alpha$-Cre recombinase mice to generate a forebrain-specific deletion in GR expression (FBGRKO) (Boyle et al, 2005, 2006). Male FBGRKO mice show a progressive deletion of the floxed GR region at 3-6 months of age in the $\mathrm{HC}$, cortex, basolateral nucleus of the amygdala (BLA) and the NAc. This deletion results in HPA axis hyperactivity. Circadian basal and peak cort were increased, as well as post-stress cort and ACTH concentrations, relative to controls. Post-stress CRH mRNA, as well as basal and post-stress AVP mRNA, was increased in the PVN, compared with controls. FBGR is also important for negative feedback regulation of the HPA axis as FBGRKO 
mice were unable to suppress cort release in dexamethasone suppression testing. See Table 1 for details of the genetic modification, as well as the behavioral testing showing depressive-like behavior in these mice.

There is a striking sex difference in FBGR regulation of the HPA axis. Female FBGRKO mice show no dysregulation of the HPA axis, no increase in basal or stress-induced cort, and no post-stress alterations in AVP or CRH in the PVN (Solomon et al, 2012). Sex differences were also evident in FBGRKO behavioral testing for depressive-like behavior (Table 1). The basis for this critical difference is unknown but possibilities include estrogen modulation of GR circuitry or different GR circuitry in females. Because loss of GR occurred in several forebrain regions, identification of the specific region(s) and the projections that are responsible for these GR-based sex differences in stress responsiveness are unknown. Additional findings could have therapeutic implications for treating psychiatric disorders in differently in males and females (Seney and Sibille, 2014).

PVN GR deletion. The PVN is a major site of physiologic homeostasis. PVN GR is the principal mediator of feedback regulation that coordinates the appropriate HPA axis response with the exposed stressor. GR mediates this negative feedback, and is therefore critical for the return of homeostasis to the HPA axis following stress exposure. To investigate the role of $\mathrm{GR}$ in $\mathrm{CRH}$ expressing neurons, deletion of GR was targeted to the PVN. GR ${ }^{\text {flox/+ }}$; Sim 1 Cre mice were generated by mating mice with exon II of the GR allele flanked by loxp sites to a Sim 1-Cre recombinase BAC transgenic line (Balthasar et al, 2005). Single-minded 1 (Sim1) encodes a transcription factor essential for formation of the hypothalamic PVN. Sim 1 promoter-driven expression of Cre begins during embryonic development and after birth in the PVN, supraoptic and posterior hypothalamic nuclei. $G R^{f l o x /+}$; Sim 1 Cre mice carry a functional wild-type and floxed GR allele, which may more closely mimic defective GR signaling in human pathologies, rather than complete loss of function. These mice show a significant decrease in GR protein in the PVN but normal levels in the pituitary and adrenal glands. $G R^{\text {flox/+}}$; Sim 1 Cre mice display enhanced $\mathrm{CRH}$ immunoreactivity in the PVN, and elevated concentrations of plasma ACTH and cort, indicating that decreased PVN GR activity influences CRH regulation and the ensuing impaired maintenance of normal HPA axis function.

In a separate study, Sim1Cre BAC transgenic mice (Balthasar et al, 2005) were mated to mice with loxp sites flanking the exon 1C-2 region of the GR allele (Boyle et al, 2005; Brewer et al, 2003) containing promoter elements, translation start site, and the transcriptional activation domain (Sim1Cre-GRe2A) (Laryea et al, 2013). Sim1CreGRe2A mice show a $43 \%$ loss of PVN GR expression. However, there were no observed differences in HPA axis responsiveness, as measured by cort, ACTH or $\mathrm{CRH}$ concentrations, under basal or stressed conditions in Sim1Cre-GRe2A and control mice (Laryea et al, 2013).
In contrast, mice with GR exon 3 deletion in the PVN (Sim1Cre-GRe3A) (Tronche et al, 1999) demonstrate an $87 \%$ reduction in PVN GR expression and display stunted growth at birth, adult obesity and impaired stress-induced glucose release (Laryea et al, 2013). Sim1Cre-GRe3s mice display elevated cort concentrations under basal and stressful conditions, and an impaired response to the dexamethasone (GR agonist) suppression test, which interrogates the integrity of feedback inhibition on the HPA axis, indicating an inability to suppress cort regulation in response to high circulating cort concentrations. In addition, Sim1Cre-GRe3A mice also display elevated PVN CRH expression and basal ACTH plasma levels (Figure 2). Thus, the loss of PVN GR activity observed in Sim1Cre-GRe3s mice results in severe hyperactivity of the HPA axis response and a Cushing's syndrome-like phenotype. In contrast to GR deletion in the pituitary (Schmidt et al, 2009), compensation does not occur in response to GR deletion but instead HPA axis hyperactivation persists into adulthood while circadian rhythm of GC secretion is retained.

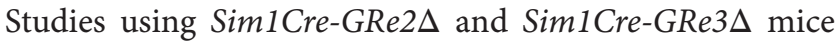
indicated that conditional deletion of GR exon 3 in the PVN resulted in increased PVN CRH mRNA, increased plasma $\mathrm{ACTH}$, and GC excess. In contrast, deletion of the GR exon $1 \mathrm{C}-2$ region produced intact $\mathrm{HPA}$ axis function. The differences observed between Sim1Cre-GRe2s and Sim1Cre-GRe3 $\Delta$ mice could be due to production of a truncated, but still functional, GR product in Sim1CreGRe2 $\Delta$ mice or differences in deletion efficiency.

Before the generation of Sim1Cre transgenic mice, studies focused mainly on deletion of exons 2 and 3 of GR. The Sim1Cre lines have been the most selective models of genetic alteration of PVN GR function thus far. As a result of these studies, further insight into the role of PVN GR in regulating HPA axis activity, behavior, and physiologic function has developed. These models allow for many potential avenues of investigation in the future including the role of PVN GR in the pathogenesis of affective disorders and pharmacologic GC therapies.

Pituitary GR deletion. Normal pituitary function is essential for HPA axis regulation in response to stress. CRH and AVP released from the hypothalamus bind to pituitary corticotrophs, triggering the release of ACTH which, in turn, causes GC secretion from the adrenal glands. GR in the anterior pituitary serves as a site of negative feedback regulation to suppress HPA axis activity, and thus, loss of pituitary GR would be expected to result in HPA axis hyperactivity. Direct genetic manipulation of pituitary GR was performed using Cre-recombinase driven by the POMC promoter. POMC is a polypeptide precursor to the ACTH peptide. Its expression begins during embryogenesis in the anterior pituitary and arcuate nucleus (Elkabes et al, 1989) (Hindelang et al, 1990). Mice with the POMC-Cre transgene were crossed to mice floxed for GR to delete GR in the anterior pituitary (GR ${ }^{\text {POMCCre }}$ ) (Schmidt et al, 2009). 
TABLE 1 Extrahypothalamic Regions: Details of Genetic Alterations, Behavioral Tests, and Behavioral Effects

\begin{tabular}{|c|c|c|c|c|c|c|}
\hline Region & Gene & Alteration & Method & Stressor/Behavior test & Behavioral effect & Reference \\
\hline \multirow[t]{26}{*}{ I. Forebrain } & GR & Deletion-males & $\begin{array}{l}\text { Floxed GRexIc-2 } \times \text { CamKII } \\
\text { (FB-spec promoter)-Cre }\end{array}$ & Forced swim & Increased despair & Boyle et al (2005) \\
\hline & & & & Tail suspension & Increased despair & \\
\hline & & & & Sucrose preference & Depression (anhedonia) & \\
\hline & & & & Motor battery & Normal & \\
\hline & & & & Forced swim+imipramine & No despair & \\
\hline & & & & $\begin{array}{l}\text { Tail suspension } \\
\text { +imipramine }\end{array}$ & No despair & \\
\hline & & Deletion-males & $\begin{array}{l}\text { Floxed GRexIc- } 2 \times \text { CamKIII } \\
\text { (FB-spec promoter)-Cre }\end{array}$ & Forced swim & Increased despair & $\begin{array}{l}\text { Solomon et al } \\
\qquad(2012)\end{array}$ \\
\hline & & & & Sucrose preference & Depression (anhedonia) & \\
\hline & & Deletion-female & $\begin{array}{l}\text { Floxed GRexIc-2 } \times \text { CamKII } \\
\text { (FB-spec promoter)-Cre }\end{array}$ & Forced swim & Normal & \\
\hline & & & & Sucrose preference & Normal & \\
\hline & $M R$ & Deletion & Floxed MRex3 × CaMKCre & Morris water maze & Impaired learning & $\begin{array}{l}\text { Berger et al } \\
(2006)\end{array}$ \\
\hline & & & & Radial maze & Impaired working memory & \\
\hline & & & & Novel object & Increased exploration & \\
\hline & & & & Anxiety tests & Normal & \\
\hline & $M R$ & Overexpression & $\begin{array}{l}\text { CaMKIl } \alpha \text { promoter directs } \\
\text { expression of a } 3 \times \text { Flag-tagged } \\
\text { mouse MR cDNA-transgene }\end{array}$ & Open field & Decreased anxiety & $\begin{array}{l}\text { Rozeboom et al } \\
\text { (2007) }\end{array}$ \\
\hline & & & & Elevated plus maze & Decreased anxiety & \\
\hline & GR:MR & $\begin{array}{l}\text { Under-:over- } \\
\text { expression }\end{array}$ & $\begin{array}{l}\text { Male mice heterozygous for a } \\
\text { null allele of GR } \times \text { female mice } \\
\text { over-expressing human MR in } \\
\text { the forebrain under the } \\
\text { control of the CamKlla } \\
\text { promoter }\end{array}$ & $\begin{array}{l}\text { Water maze: spatial \& } \\
\text { reversal learning, swim } \\
\text { path time }\end{array}$ & Dependent on genotype & $\begin{array}{l}\text { Harris et al } \\
(20 \mid 3)\end{array}$ \\
\hline & & & & Passive avoidance & Dependent on genotype & \\
\hline & & & & Light dark box & Normal & \\
\hline & & & & Open field & Normal & \\
\hline & & & & Elevated plus maze & Normal & \\
\hline & & & & Tail suspension & Normal & \\
\hline & $\mathrm{CRH}$ & Overexpression & $\begin{array}{l}\text { Tetop-CRH males } \times \text { CaMKII- } \\
\text { tTA females }\end{array}$ & $\begin{array}{l}\text { Open field; light/dark } \\
\text { preference }\end{array}$ & Increased anxiety & $\begin{array}{l}\text { Kolber et al } \\
(2010)\end{array}$ \\
\hline & & FBCRHOE & $\begin{array}{l}\text { (off doxy, overexpression on, } \\
\text { for lifetime) }\end{array}$ & & $\begin{array}{l}\text { * Confounded by } \\
\text { Cushingoid locomotor } \\
\text { changes }\end{array}$ & \\
\hline & & $\mathrm{FBCRHOE}^{\mathrm{dev}}$ & (off doxy from EI2-PI4) & $\begin{array}{l}\text { Open field; light/dark } \\
\text { preference }\end{array}$ & Increased anxiety & \\
\hline & & & & $\begin{array}{l}\text { Tail suspension, forced } \\
\text { swim }\end{array}$ & Depression & \\
\hline \multirow[t]{3}{*}{ 2. Dorsal raphé } & GR & Deletion & $\begin{array}{l}\text { Floxed GR males } \\
\text { stereotaxically injected with } \\
\text { AAV2/9 Cre or AAV2/9-GFP }\end{array}$ & Open field, elev. plus maze & Anxiolytic & $\begin{array}{c}\text { Vincent and } \\
\text { Jacobson (20|4) }\end{array}$ \\
\hline & & & & Forced swim & Anti-depressant & \\
\hline & & & & $\begin{array}{l}\text { Social interaction/ } \\
\text { exploration }\end{array}$ & Increased & \\
\hline $\begin{array}{l}\text { 3. Dopamine circuit } \\
\text { (dopaminoceptive: } \\
\text { nucleus accumbens, dorsal } \\
\text { striatum, cortex) }\end{array}$ & GR & $\begin{array}{l}\text { Dopaminoceptive } \\
\text { deletion }\end{array}$ & $\begin{array}{l}\mathrm{Nr} 3 \mathrm{cl}(\mathrm{GR}) \mathrm{loxP} / \\
\text { loxP } \times \text { TgYAC-D IaCre mice }\end{array}$ & $\begin{array}{l}\text { Social interaction after } \\
\text { repeated social defeat }\end{array}$ & $\begin{array}{l}\text { Loss of normal social } \\
\text { aversion response to } \\
\text { repeated defeat }\end{array}$ & Barik et al (20|3) \\
\hline \multirow[t]{4}{*}{ 4. Pre-frontal cortex } & ilPFC GR & Deletion & $\begin{array}{l}\text { Different LV-short-hairpin (sh) } \\
\text { RNA constructs targeting GR } \\
\text { exon I stereotaxically }\end{array}$ & Forced swim & $\begin{array}{l}\text { Depressant: increased } \\
\text { immobility }\end{array}$ & $\begin{array}{l}\text { McKlveen et al } \\
\text { (2013) }\end{array}$ \\
\hline & & & & Open field & No effect & \\
\hline & PIPFC GR & Deletion & $"$ & Forced swim & No effect & \\
\hline & & & & Open field & $\begin{array}{l}\text { No increased effect, but } \\
\text { increased locomotor } \\
\text { activity }\end{array}$ & \\
\hline \multirow[t]{2}{*}{$\begin{array}{l}\text { 5. Amygdala (central } \\
\text { nucleus) }\end{array}$} & GR & Deletion & $\begin{array}{l}\text { Floxed GR exon } 2 \text { males } \\
\text { stereotaxically injected with } \\
\text { LV-Cre }\end{array}$ & $\begin{array}{l}\text { Conditioned } \\
\text { fear-contextual }\end{array}$ & $\begin{array}{l}\text { Deficit in freezing during } \\
\text { testing }\end{array}$ & $\begin{array}{c}\text { Kolber et al } \\
(2008)\end{array}$ \\
\hline & & & & $\begin{array}{l}\text { Conditioned } \\
\text { fear-auditory cue }\end{array}$ & $\begin{array}{l}\text { Deficit in freezing during } \\
\text { testing }\end{array}$ & \\
\hline
\end{tabular}


TABLE 1 (Continued)

\begin{tabular}{|c|c|c|c|c|c|c|}
\hline Region & Gene & Alteration & Method & Stressor/Behavior test & Behavioral effect & Reference \\
\hline & & & & $\begin{array}{l}\text { Proceptive sexual } \\
\text { behavior }\end{array}$ & Decreased libido & \\
\hline & $\mathrm{CRH}$ & $\begin{array}{l}\text { Chronic } \\
\text { overexpression CeA } \\
\text { CRHOE }\end{array}$ & $\begin{array}{l}\text { Stereotaxic injection of male } \\
\text { mouse CeA with LV-CRH }\end{array}$ & Acoustic startle & Lower anxiety & $\begin{array}{l}\text { Regev et al } \\
(2011)\end{array}$ \\
\hline & & & & Post-stress acoustic startle & Lower anxiety & \\
\hline & & & & Light/dark preference & Lower anxiety & \\
\hline & & & & Forced swim & No effect & \\
\hline & & & & Tail suspension & No effect & \\
\hline & $\mathrm{CRH}$ & $\begin{array}{l}\text { Knockdown CeA } \\
\text { CRHKD }\end{array}$ & $\begin{array}{l}\text { Stereotactic injection of male } \\
\text { mouse CeA with LV-short- } \\
\text { hairpin (sh)RNA constructs } \\
\text { targeting CRH }\end{array}$ & Elev. plus maze & Decreased anxiety & $\begin{array}{l}\text { Regev et al } \\
(2012)\end{array}$ \\
\hline & $\mathrm{CRH}$ & $\begin{array}{l}\text { Short-term } \\
\text { overexpression CeA } \\
\text { CRHOE }\end{array}$ & $\begin{array}{l}\text { Stereotaxic injection of male } \\
\text { mouse CeA with LV-rtTA-GFP } \\
\text { and LV-tetop-CRH-RFP } \\
\text { (tet-on) }\end{array}$ & Light/dark preference & No effect & $\begin{array}{l}\text { Regev et al } \\
\quad(2012)\end{array}$ \\
\hline & & & & $\begin{array}{l}\text { Restraint stress, then light/ } \\
\text { dark preference }\end{array}$ & Increased anxiety & \\
\hline \multirow[t]{4}{*}{ 6. BnST } & $\mathrm{CRH}$ & $\begin{array}{l}\text { Chronic } \\
\text { overexpression BnSt } \\
\text { CRHOE }\end{array}$ & $\begin{array}{l}\text { Stereotaxic injection of male } \\
\text { mouse Bnst with LV-CRH }\end{array}$ & Acoustic startle & No effect & $\begin{array}{l}\text { Regev et al } \\
(2011)\end{array}$ \\
\hline & & & & Post-stress acoustic startle & No effect & \\
\hline & & & & Light/dark preference & No effect & \\
\hline & & & & Forced swim & Depression & \\
\hline
\end{tabular}

The HPA axis of $\mathrm{GR}^{\text {POMCCre }}$ mice evaluated at postnatal day 6 displayed reduced PVN CRH mRNA levels, but increased PVN AVP mRNA. As would be expected, hypothalamic drive of elevated AVP activity results in increased basal plasma levels of ACTH and subsequently increased plasma cort concentrations in $\mathrm{GR}^{\mathrm{POMCC} e}$ mice compared with controls. Loss of pituitary GR also led to reduced PVN GR mRNA levels (Schmidt et al, 2009). These differences in HPA axis activity between $\mathrm{GR}^{\text {POMCCre }}$ and control mice are short-lived, only occurring in the early postnatal days. In adulthood, these changes are normalized. However, the consequences of having an early-life disruption in HPA axis regulation led to a blunted dexamethasonemediated cort suppression response in $\mathrm{GR}^{\text {POMCCre }}$ mice in adulthood. Moreover, adult $\mathrm{GR}^{\text {POMCCre }}$ mice had a reduced ability to suppress cort after a 30 -min restraint stress. These data imply that disruption of pituitary HPA axis function in early development, through GR deletion, can produce disrupted HPA axis activity in the neonatal period and altered stress reactivity in adulthood.

GR deletion in dopamine neurons. Psychosocial stressors increase GCs and the excitability of dopamine (DA) pathways. The role of GR in DA circuitry was explored using floxed GR mice crossed with dopaminoceptive/ dopaminergic-specific Cre mice (Ambroggi et al, 2009). GR in dopaminoceptive neurons projecting from the ventral tegmental area (VTA) of the brainstem to the NAc, cortex, and dorsal striatum is critical for the normal social aversion response to repeated aggression stress (Barik et al, 2013). Deletion of GR specifically in NAc neurons $\left(\mathrm{GR}^{\mathrm{D1Cre}}\right.$ mice) completely abrogates the development of social aversion, while mice with deletion of GR in dopaminergic neurons of the VTA $\left(\mathrm{GR}^{\text {DATCre }}\right)$ develop social aversion normally. This is not due to differences in post-stress cort concentrations or alterations in fear memory. Instead, GR appears to modulate a post-stress increase of DA release in the NAc by increasing firing of VTA neurons, as $\mathrm{GR}^{\mathrm{D1Cre}}$ mice exhibit no DA release in the NAc, and no increase in VTA firing after an acute social defeat stress. The GR circuitry controlling DA synaptic firing is unclear. This mouse model points out the exquisite neuroanatomical specificity of GR function in the brain, as well as the complex interactions between GCs and neurotransmitter mediation of stress.

GR deletion in the dorsal raphé nucleus. GR interacts with serotonergic as well as dopaminergic stress signaling pathways, both of which can modulate HPA axis activity. The brainstem dorsal raphe nucleus (DRN) provides the majority of serotonergic input to the forebrain, a region critical for mood and emotions. Floxed GR mice were injected with adeno-associated virus pseudotype AAV2/9 


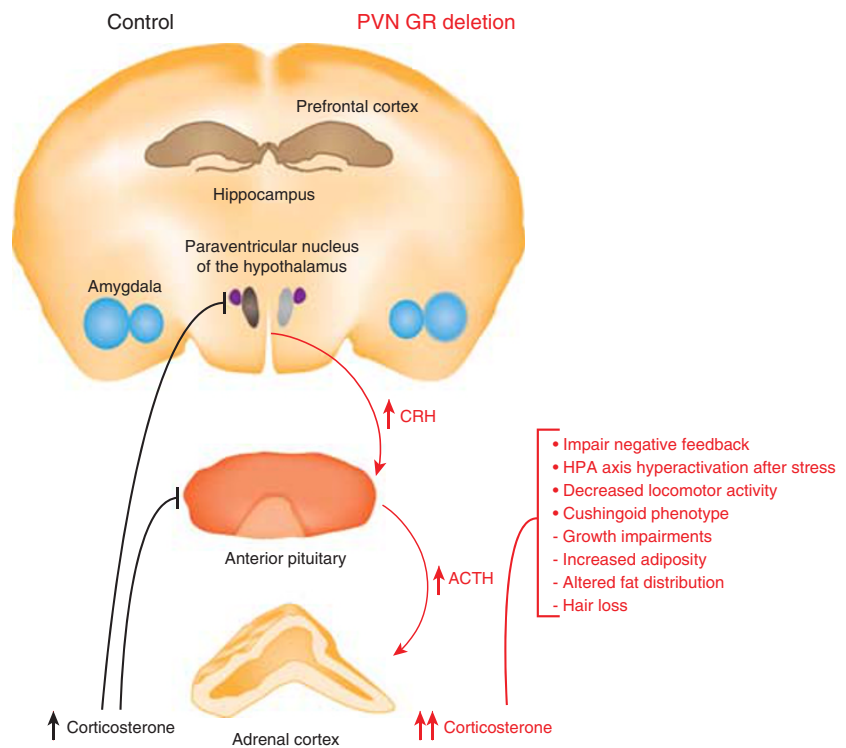

Figure 2. HPA axis regulation in PVN GR exon 3-deleted mice (Sim1CreGRe3 $\Delta$ ). Left side: Control-Under normal circumstances, cort acts on glucocorticoid receptors (red dots) at negative feedback sites in the pituitary and PVN to inhibit further HPA axis activation. Right side: PVN GR deletion - Loss of PVN GR (shaded yellow region) prevents cort-feedback inhibition of the HPA axis and leads to increased PVN CRH and increased plasma ACTH that further elevate cort levels. The chronic glucocorticoid excess leads to impaired negative feedback, exaggerated stress-induced HPA axis activation, locomotor deficits, and a Cushingoid phenotype.

expressing either Cre recombinase (DRNGRKO) or GFP (DRN-GFP) to determine the effects of DRN GR on activity of the HPA axis during stress (Vincent and Jacobson, 2014). DRN GR is necessary for normal HPA-negative feedback after acute stress, as cort concentrations of DRNGRKO mice are significantly higher than in GFP controls. See Table 1 for several behaviors altered in DRNGRKO mice.

GR deletion in the CeA. The amygdala, a limbic site, contains several nuclei, all important in modulating stress. The CeA is a key node for integrating stress inputs from other brain regions and is the major output center to other regions impacting stress behavior (Pape, 2005). Acute stress causes release of CRH not only from the PVN, but also from the CeA. GC activation of the CeA has been implicated in positive feedback to the HPA, suggesting a role in hyperactive stress responsivity. An essential role for GR specifically in fear conditioning has been discovered using lentivirus-Cre injections into the CeA of floxed-GRex 1C-2 mice (Kolber et al, 2008). These CeAGRKO mice have deficient conditioned fear responses as well as diminished post-stress cFos and CRH induction, although cort release and other anxiety testing were normal.

PFC GR deletion. The PFC has numerous connections with limbic areas of the brain, and with the hindbrain, and thus, can translate stressful emotional input into appropriate cognitive responses. PFC GR has distinct roles in the response to chronic stress depending on the subregion, as each subregion has connections to different areas of the brain. A knockdown strategy using short hairpin RNAs was used to test the role of GR in different subregions (see Table 1 for targeting strategy and behavioral sequelae). Infralimbic PFC GR knockdown (iLPFC GRKD) hypersensitized the HPA response to stress with increased cort and ACTH concentrations after acute restraint stress and even higher cort concentrations following chronic variable stress (CVS) and additional acute stress. Rats with pre-limbic PFC GR knockdown (plPFC GRKD) also had increased cort release after acute restraint, but lower levels than controls following CVS. Baseline cort levels were unaffected in chronically stressed iLPFC GRKD rats, but were significantly increased in pick GRKD rats (McKlveen et al, 2013). These major differences in GR regulation of HPA stress circuitry are dependent on specific regions of the PFC reinforce the neuroanatomic complexity of GR signaling. This section demonstrates the broad effects of GR deletion in different regions of the brain.

\section{Mineralocorticoid Receptor}

In the brain, MRs are mainly localized to the $\mathrm{HC}$, but are also expressed throughout the limbic system and in the hypothalamus (de Kloet et al, 2000; De Kloet et al, 1998; Reul and de Kloet, 1985). Hippocampal MRs have a primary role in the GC-mediated feedback regulation of the HPA axis (Jacobson and Sapolsky, 1991; Reul et al, 2000), facilitating the maintenance of basal HPA axis activity at the nadir of the circadian rhythm (Dallman et al, 1989; De Kloet et al, 1998). While many studies have addressed the role of GRs in mediating the effects of GCs in regulating HPA axis activity, far less is known about the function of MR. Below, we discuss the contributions made to understanding the role of MR in regulating HPA axis activity by deleting, and overexpressing, MR expression specifically in the forebrain $\left(\mathrm{MR}^{\mathrm{CaMKCre}}\right)$ (FBMRov), respectively. In addition, we discuss a gene targeting method that disrupts both MR and GR levels to explore the importance of MR/GR balance in HPA axis regulation.

Forebrain MR deletion. MR has a higher binding affinity for cort than GR and can co-dimerize with GR in regions where both are expressed, and thus, modulate the actions of GR (Rozeboom et al, 2007). Early perinatal forebrain-specific deletion of mouse MR ( $\left.\mathrm{MR}^{\mathrm{CaMKCre}}\right)$ causes upregulation of GR expression and abnormal sprouting of mossy fibers in the HC, but no effect in basic synaptic transmission or in circadian or post-restraint stress cort concentrations. Thus, forebrain $\mathrm{MR}$ is not required for regulation of circadian or stress HPA axis activity (Berger et al, 2006). Numerous behavioral abnormalities are present in $\mathrm{MR}^{\mathrm{CaMKCre}}$ mice (Table 1), presumably a consequence of an increased GR:MR ratio and mossy fiber aberrations.

Forebrain $M R$ overexpression. Conversely, chronic overexpression of forebrain MR (FBMRov) resulted in transgene overexpression, specifically in the HC and cortex, 
which decreased hippocampal GR expression in males, but only trending toward a decrease in females (Rozeboom et al, 2007). The MR:GR ratio is increased more in males than in females. Circadian and post-restraint cort levels in FBMRov males were similar to controls but post-restraint cort release was suppressed in FBMRov females. The serotonin receptor is also decreased in FBMRov mice, which would contribute to the reduced anxiety behaviors observed following acute stress in both sexes (Table 1). These results indicate that MR overexpression modulates anxiety behaviors via a different (non-sexually dimorphic) pathway than its modulation of the HPA response to stressors.

GR:MR balance. A different genetic approach used crosses between GR-underexpressing and MR-overexpressing mice to explore how the GR:MR balance affected the HPA axis. GR ${ }^{\text {lo }}$ $\mathrm{MR}^{\text {hi }}$ mice overexpress forebrain MR while globally underexpressing GR (Harris et al, 2013). These crosses also generated $\mathrm{GR}^{\text {lo }} \mathrm{MR}^{\text {norm }}, \mathrm{GR}^{\text {norm }} \mathrm{MR}^{\text {hi }}$, and $\mathrm{GR}^{\text {norm }} \mathrm{MR}^{\text {norm }}$ littermates. $M R$ and GR interacted significantly in regulation of the HPA axis after restraint stress, but not under basal conditions. Elevated cort release in response to stress in $\mathrm{GR}^{\mathrm{lo}} \mathrm{MR}^{\text {norm }}$ male mice was ameliorated, which suggested that MR could compensate for inadequate post-stress negative feedback by GR in $\mathrm{GR}^{\text {lo }}$ mice. The GR:MR balance was also essential for normal behavioral responses to stress (Table 1). These gene targeting studies of GR and MR in different neuroanatomical regions of the brain point to a highly complex orchestration of GC signaling pathways, which can be sexually dimorphic, and sometimes include interactions with non-HPA stress signaling pathways, eg, neurotransmitters.

$M R$ and GR in the periphery. Whereas expression of GR and $M R$ in the brain overlaps, peripheral expression is much more isolated. GR is expressed almost ubiquitously in the periphery while MR expression is localized to allow its function in controlling blood pressure, maintaining water and electrolyte balance, and sympathetic drive to the periphery (Gomez-Sanchez, 2011). The liver and the kidney are primary sites of peripheral cortisol metabolism. Each expresses the enzyme 11- $\beta$ hydroxysteroid dehydrogenase type II, $11 \beta$-HSD2, which converts GCs, cortisol in humans, to an inactive metabolite, cortisone. In humans, aldosterone and cortisol have similar affinities for MR. 11 $\beta$-HSD2 activity is important to prevent overstimulation of MR by cortisol. Congenital deficiency of $11 \beta$-HSD2 in humans (DaveSharma et al, 1998) or transgenic deletion in mice (Kotelevtsev et al, 1999) results in a clinical condition termed apparent MR excess (AME) syndrome. Affected subjects, despite having normal circulating levels of cortisol and no disturbances of the HPA axis, present with sodium retention, hypertension, and hypokalemia (Anagnostis et al, 2009; Gathercole and Stewart, 2010). This condition develops due to the overactivation of cortisol by MRs because the body lacks the ability to inactivate cortisol.

\section{Corticotropin-Releasing Hormone}

$\mathrm{CRH}$ is a 41 amino-acid peptide synthesized not only in several brain regions, but also in the periphery. Under basal conditions, $\mathrm{CRH}$ is secreted by the hypothalamus into the portal system in a circadian manner. This diurnal pattern can be altered by changes in the light:dark schedule, activity levels, and feeding times, and is disrupted by stress. In response to physiologic and psychologic stressors, the HPA axis is activated and $\mathrm{CRH}$ and AVP secretions are markedly increased (Bonfiglio et al, 2011). CRH is also widely expressed in extrahypothalamic regions of the CNS, and thus can act as a neuroregulator in forebrain and limbic circuitry. CRH expression is regulated in different ways, depending on the location of expression. CRH gene transcription in the PVN, is inhibited by GCs. In contrast, GCs increase CRH expression in the amygdala and the lateral BnST (Herman et al, 2012). Two CRH receptors, CRHR1 and CRHR2, modulate the effects of $\mathrm{CRH}$, each in a very distinct way, as they have different binding affinities and are located in different regions of the brain. The role of $\mathrm{CRH}$ as a primary mediator of HPA axis regulation has been studied in a mouse model of $\mathrm{CRH}$ deficiency ( $\mathrm{CRH} \mathrm{KO}$ mice). The roles of $\mathrm{CRH}$ receptors and the extrahypothalamic roles for $\mathrm{CRH}$ have also been studied with several different regionspecific gene disruption models, as described below.

CRH deletion. In rodents, adrenal cort production peaks just before the active period, or the dark phase in a light:dark cycle. Circadian modulation of HPA axis activity is required to establish the daily rhythm of cort production but the exact mechanism(s) for establishing the circadian cort profile has not been completely elucidated. $\mathrm{CRH}$ has been shown to have an important role in peak cort concentration as $\mathrm{CRH}$ mRNA rises just before the active period and falls before the sleep phase in rodents (Kwak et al, 1993). The generation of $\mathrm{CRH}$-deficient mice ( $\mathrm{CRH} \mathrm{KO}$ ), produced by homologous recombination of a gene targeting vector in which all protein coding regions were removed in embryonic stem cells, has helped to define the role of $\mathrm{CRH}$ in normal diurnal cort production (Muglia et al, 1995). The normal circadian variations in plasma cort concentration are not present in female $\mathrm{CRH} \mathrm{KO}$ mice and serum cort concentration was below assay sensitivity in $\mathrm{CRH} \mathrm{KO}$ males at both circadian peak and nadir. Although plasma cort concentrations remain low in $\mathrm{CRH} \mathrm{KO}$ mice, plasma ACTH did not increase above circadian nadir concentrations, and following adrenalectomy, there was no circadian peak or nadir increase in plasma ACTH in KO mice (Muglia et al, 1997).

CRH KO mice show an abnormal, sexually dimorphic response to stress. Following 20 min of restraint stress, male $\mathrm{CRH}$-deficient mice showed a significant reduction in plasma cort concentrations compared with wild-type mice, however, females showed a ninefold greater cort response than male KO (Muglia et al, 1995). Thus, CRH insufficiency results in hypo-responsiveness to a variety of stressors and produces adrenal atrophy (Jacobson et al, 2000). 
CRH KO mice demonstrate a tendency toward elevated hypothalamic AVP mRNA. Despite chronic cort insufficiency, basal pituitary POMC mRNA and ACTH protein, as well as plasma ACTH levels, are not increased in CRH KO mice. The lack of elevation in POMC mRNA and plasma ACTH levels in the adrenal glands of CRH KO mice indicates an impaired response to GC insufficiency with $\mathrm{CRH}$ loss. Following adrenalectomy, POMC mRNA increases in both wild-type and $\mathrm{KO}$ mice, suggesting that $\mathrm{CRH}$ activity is not required for changes in POMC expression in response to GC insufficiency. Plasma ACTH does not increase following adrenalectomy, suggesting that corticotrophs require $\mathrm{CRH}$ for secretion of ACTH but are less dependent on CRH for increases in POMC mRNA.

Thymus weight, an indicator of overall GC status in rodents, increases with decreased thymus cort exposure. Thymus weight was significantly increased in CRH KO mice, suggestive of deficient GC activity in KO mice. Loss of GC activity has also been reported to result in depletion of white fat stores (Dallman et al, 1993). CRH KO males showed significantly reduced white fat composition in comparison with wild-type males. Female $\mathrm{CRH}$ KO mice displayed a similar trend but it did not reach the level of significance, consistent with the less significant deficit in adrenocortical function. The increase in thymus size and decreased white fat stores indicate that $\mathrm{CRH}$ KO mice display chronically deficient GC action (Muglia et al, 2000).

In summary, $\mathrm{CRH}$-deficient mice lack the normal diurnal GC rhythm and show an impaired and sexually dimorphic cort response to stress, elevated hypothalamic AVP expression, and adrenal atrophy. In addition, CRH KO mice display loss of circadian variations in plasma ACTH, normal circadian locomotor activity, basal pituitary POMC mRNA and ACTH peptide and show reduced white fat stores and increased thymus weight.

Forebrain CRH Overexpression. In addition to the PVN, $\mathrm{CRH}$ is also expressed in several areas of the forebrain (Laryea et al, 2012). The role of extrahypothalamic CRH on development of HPA axis and behavioral responses to stress in early life was investigated using a tetracycline-off, forebrain-inducible CRH overexpression model (FBCRHOE) (Kolber et al, 2010). See Table 1 for details of the gene disruption method and behavioral sequelae. For control of the tetracycline-off system, mice were fed doxycycline chow to repress transgene expression. FBCRHOE ${ }^{\mathrm{dev}}$ were off doxycycline from embryonic day (E) 0 through postnatal day 21 (PN21) for transient elevation of forebrain CRH during mouse brain development. FBCRHOE ${ }^{\text {life }}$ mice were off doxycycline their entire lives and continuously exposed to CRH overexpression (Kolber et al, 2010). During the time they are off doxycycline, $\mathrm{CRH}$ in these mice is increased in forebrain regions including $\mathrm{HC}$, cortex, and amygdala. Several of these regions are considered part of the limbic system, the area of the brain associated with emotions, memory, and behavior. Because CRH activates the HPA axis, hyperactive HPA axis activity throughout life resulted in increased cort and ACTH levels at circadian nadir (but not peak) in FBCRHOE ${ }^{\text {life }}$ mice, which displayed a Cushingoidlike phenotype as a result. In contrast, adult FBCRHOE ${ }^{\text {dev }}$ mice displayed anxiogenic and despair-like behavioral abnormalities (Table 1), although they had normal circadian, as well as post-restraint stress, cort and ACTH levels. Expression of a CRH receptor, CRHR1, is increased in FBCRHOE $^{\mathrm{dev}}$ adult mice. FBCRHOE ${ }^{\mathrm{dev}}$ adult stress physiology is normal, these data suggest that the behavioral abnormalities present in FBCRHOE ${ }^{\mathrm{dev}}$ adults have developmental origins, possibly due to excess $\mathrm{CRH}$ alterations in responsiveness/circuitry of CRH signaling pathways, including $\mathrm{CRH}$ receptors, during neuronal development.

CRH Overexpression in the CeA and BnST. CRH is normally upregulated after certain stressors and typically only CRH from the PVN directly activates the HPA axis (Kolber et al, 2008). Several different gene-disruption models have shed light on the role of extrahypothalamic CRH expression found in the specific forebrain region designated the 'extended amygdala', which consists of the CeA, the $\mathrm{BnST}$, their reciprocal projections, and their projections to the PVN. Continuous lentiviral overexpression of CeA CRH in female rats resulted in upregulation of the HPA axis and increased expression of CRH and AVP in the PVN (KeenRhinehart et al, 2009). Negative feedback regulation of the HPA axis is also dysregulated in female CeA CRHOE rats in a time-dependent manner as assessed by a dexamethasone suppression test. Increased CeA CRH also impacts female reproductive physiology: the diestrus phase of the estrus cycle is lengthened and gonadotropin releasing hormone expression is reduced, resulting in a lengthened diestrus phase, thus longer estrus cycles. Emotionality is affected as well (Table 1).

Continuous lentiviral overexpression of $\mathrm{CRH}$ (for 4 months) in the CeA of male mice did not alter HPA activity as measured by plasma cort under basal and postrestraint stress conditions, nor did continuous overexpression of CRH in male mouse BnSt (via stereotactic injection of LV-CRH) (Regev et al, 2011). It is unclear whether the differences between female rats and male mice in central HPA effects from CeA CRHOE are due to sexual dimorphism, species differences, or a combination of both. Behavioral sequelae in response to prolonged $\mathrm{CRH}$ overexpression were different depending on the site of CRHOE, whether in the mouse BnST or CeA (Table 1), thus, stress behaviors are acutely sensitive to site-specific CRH levels. This may also be a result of alterations in CRHR1 expression, which were also dependent on the region with $\mathrm{CRH}$ overexpression.

Overexpression vs knockdown of CeA CRH. Regev et al (2012) also generated two complementary systems to further delineate the function of CeA CRH in male mice: CeA CRH knockdown using lentiviral shCRH RNAs (short-hairpin RNAs that interfere with CRH mRNA (CeA CRHKD)), and a tet-inducible CeA CRH overexpressing model (CeA CRHOE). Both models demonstrate short-term alterations in CRH levels (). CeA CRHKD results in elevated basal cort 
concentrations, suggesting a role for $\mathrm{CeA} \mathrm{CRH}$ in regulating basal (circadian) HPA activity. Post-restraint stress plasma cort concentrations were not affected, although several stress behaviors were altered (Table 1). In short-term CRHOE (for 3 days) mice, circadian and post-stress cort concentrations were normal, although the overexpression resulted in increased anxiety behavior post-stress (Regev et al, 2012). Thus, normal levels of CeA CRH are essential for regulation of basal HPA activity, and short-term overexpression does not impair central HPA physiology. However, even shortterm overexpression of $\mathrm{CRH}$ in the $\mathrm{CeA}$ affects limbic circuitry controlling anxiety behaviors.

CRHR1 and CRHR2 Deficiency. These two G proteincoupled $\mathrm{CRH}$ receptors are critical for mediating the downstream effects of $\mathrm{CRH}$. They differ in their distribution in the brain and peripheral tissues: in the mouse. CRHR1 is abundantly expressed in the cerebral cortex, cerebellum, MS, and the anterior pituitary, while CRHR2 is present in the ventromedial nuclei of the hypothalamus, lateral septum, amygdala, and entorhinal cortex in the brain, also peripherally in skeletal muscle, heart, vasculature, and gastrointestinal tract (Bale et al, 2002; Lovenberg et al, 1995). They also differ in their binding affinity for CRH, CRHR1 having a much higher affinity for CRH than does CRHR2.

CRHR1-deficient mice were generated using a targeting vector, which deleted the end of the first extracellular domain through the fourth transmembrane domain (Smith et al, 1998). CRHR1null homozygotes have very low plasma cort concentrations due to agenesis of the adrenal gland zona fasciculata, the GC-producing region. This agenesis was caused by developmental insufficiency of ACTH production in CRHR1 mutants. Adrenal gland function can be restored by early postnatal ACTH replacement. Basal ACTH levels in mutant adults were normal, but $\mathrm{CRH}$ production in the PVN was markedly increased, due to diminished negative feedback to the PVN by low cort levels. Amygdalar $\mathrm{CRH}$ production was not affected in the mutants, nor was AVP in the PVN. Loss of this receptor has the behavioral consequence of reducing anxiety. This is not due to low circulating cort concentrations in the mutants, as cort replacement had no effect. CRHR1 mutants demonstrate that CRHR1 is essential for adrenal gland development, HPA axis function, and normal behavioral responses to stress.

In contrast, CRHR2-deficient mice, generated using a targeting vector that deletes part of the fifth transmembrane domain through the seventh transmembrane domain of CRHR2, show increased anxiety in behavioral testing paradigms. Physiologically, basal levels of cort and ACTH were normal, but the CRHR2 mutants had a hypersensitive response to restraint stress: their cort concentrations and ACTH levels peaked earlier and were higher than controls.

These mutant models demonstrate opposing actions of CRHR1 and CRHR2 in the HPA axis and behavioral responses to stress. To further elucidate how these two receptors interact in $\mathrm{CRH}$ signaling of the stress response, a mouse double mutant for both receptors was generated by mating mutant
CRHR1 males with mutant CRHR2 females, generating offspring heterozygous for both genes, which were then mated to produce offspring homozygous for both mutations. Basal ACTH levels in the double mutants, as in the single mutants, were normal. However, cort concentrations at nadir were significantly lower in the double mutants than in the single CRHR1 mutants, relative to controls or single CRHR2 mutants. Also, like the single CRHR1 mutants, CRH levels are increased. Surprisingly, there is a sexual dichotomy in anxiety behaviors. Double mutant females exhibited less anxiety in anxiety tests relative to controls and similar to CRHR1 single mutants, whereas double mutant male behaviors were more anxiogenic. During this testing, CRHR1 single mutant male mice, which were reported earlier to show anxiolytic behaviors (Smith et al, 1998), were now found to have anxiety behaviors similar to controls. The difference in results was due to differences in the maternal genotype: if the mother was heteroor homozygous for the CRHR2 single mutation, then male, but not female, offspring will display anxiogenic behaviors, regardless of its genotype, indicating a highly anxious mother.

These results indicate a critical and sexually dimorphic role for both $\mathrm{CRH}$ receptors in the development and maintenance of normal HPA axis and behavioral responses to stress.

\section{Vasopressin}

$\mathrm{CRH}$ interacts intricately with vasopressin, AVP, the other ACTH secretagogue to coordinate HPA axis responsiveness. AVP levels are more closely in line with ACTH, than CRH, suggesting a more active role for AVP in regulating the HPA axis. Below, we explore the contribution of AVP signaling in HPA axis regulation.

AVP is secreted mainly from the parvocellular neurons in the PVN and also from the soma and dendrites of magnocellular neurons in the hypothalamus. AVP is a direct ACTH secretagogue through its $\mathrm{V} 1 \mathrm{~b}$ receptor. AVP regulation of the HPA axis is crucial for sustaining $\mathrm{CRH}$ responsiveness in the presence of high plasma cort concentrations.

AVP exerts major physiological effects through three receptor isoforms (V1a, V1b, and V2). Among these three subtypes, the vasopressin $\mathrm{V} 1 \mathrm{~b}$ receptor is specifically expressed in pituitary corticotrophs and mediates the stimulatory effect of AVP on ACTH release. To determine the roles of the $\mathrm{V} 1 \mathrm{~b}$ receptor in vivo, gene targeting was used to create a mouse model lacking the $\mathrm{V} 1 \mathrm{~b}$ receptor gene $\left(V 1 b R^{-/-}\right)$. In addition, Brattleboro (BB) rats, which have diminished AVP mRNA or protein, will be discussed as a model of congenital AVP deletion.

$V I b$ receptor deletion $\left(V 1 b R^{-/-}\right)$. AVP exerts its major physiological function via three distinct receptors: V1a, V1b, and V2. The vasopressin V1b receptor is expressed in pituitary corticotrophs and mediates the stimulatory effect of ACTH release from the pituitary. Basal concentrations of AVP, OT, and CRH gene expression in the PVN are normal in AVP $\mathrm{V} 1 \mathrm{bR}^{-/-}$mice. Mice lacking the $\mathrm{V} 1 \mathrm{~b}$ receptor, 
$\mathrm{V}_{1} \mathrm{bR}^{-/-}$, were generated to determine the role of $\mathrm{V} 1 \mathrm{~b}$ receptors in regulation of the HPA axis in vivo. Under basal conditions, plasma ACTH and cort concentrations were lower in $\mathrm{V}_{1} \mathrm{bR}^{-/-}$than in wild-type $\left(\mathrm{V} 1 \mathrm{bR}^{+/+}\right)$mice, during the light phase of the light:dark cycle. In the third hour of the dark phase of the light:dark cycle, plasma ACTH levels were increased in $\mathrm{V} \mathrm{bR}^{+/+}$mice, but this elevation was not present in $\mathrm{V} \mathrm{bR}^{-/-}$mice, indicating that the circadian variation was blunted in $\mathrm{V} \mathrm{bR}^{-/-}$mice. Contrary to $\mathrm{ACTH}$, cort concentrations were elevated at the dark phase compared with that of the light phase in both $\mathrm{V} \mathrm{bR}^{+/+}$and $\mathrm{V} \mathrm{bR}^{-/-}$ mice. Thus, circadian variation in cort secretion does not appear to be influenced by deletion of V1bR. Stimulation with exogenous AVP did not significantly increase circulating ACTH levels in $\mathrm{V}_{1} \mathrm{bR}^{-/-}$mice. However, exogenous $\mathrm{CRH}$ produced similar concentrations of plasma ACTH and cort concentrations were present in both wild-type and homozygous mice. Following a forced swim stressor, the significant increase in plasma ACTH present in $\mathrm{V} \mathrm{bR}^{+/+}$was impaired in $\mathrm{V} \mathrm{bR}^{-/-}$mice. Plasma cort concentrations, after the forced swim, were significantly lower in $\mathrm{V}_{1} \mathrm{bR}^{-1-}$ compared with $\mathrm{V}_{1} \mathrm{bR}^{+/+}$mice, but the increase in plasma cort above the basal concentration was comparable between groups (Tanoue et al, 2004).

In summary, $\mathrm{V}_{1 \mathrm{bR}} \mathrm{b}^{-/-}$mouse studies have shown that $\mathrm{AVP} / \mathrm{V} 1 \mathrm{~b}$ receptor signaling has an important role in maintaining basal ACTH secretion, and that both AVP/ $\mathrm{V} 1 \mathrm{~b}$ and $\mathrm{CRH} / \mathrm{CRH}$ receptor signaling have a critical role in modulating HPA axis activity in response to stress.

Single-nucleotide polymorphisms (SNPs) and haplotypes in the human AVPR1b gene, which encodes for the AVP receptor $1 \mathrm{~b}$ protein, have been associated with mood and anxiety disorders in humans (Keck et al, 2008; van West et al, 2004). Additional human studies have suggested a link between the haplotype of $A V P R 1 b$ and suicide attempts (Leszczynska-Rodziewicz et al, 2013). Furthermore, polymorphisms in the AVPR1b gene have been suggested in the involvement of childhood onset of mood disorders, in a sexually dimorphic manner (Dempster et al, 2007). Although $\mathrm{CRH}$ signaling is the principle regulator of the HPA axis, AVP signaling via the AVPR1b receptor has been shown to act synergistically with CRHR1 in response to various stress response paradigms (Scott and Dinan, 1998). An association between the rs28536160 polymorphism of the AVPR1b gene and rs1293651 of the CRHR1 gene and bipolar patients with psychotic features has been previously established (Leszczynska-Rodziewicz et al, 2012). The precise role of AVPR1b genetic variation in stress responsiveness is still somewhat unclear. Future studies should focus on geneenvironment interactions between AVPR1B variants and stressful stimuli.

$A V P$ deficiency ( $B B$ rats). $\mathrm{BB}$ rats inherit a single nucleotide deletion in the neurophysin II region of the AVP precursor, which results in abnormal AVP prohormone and consequently, the lack of functional AVP (Ivell et al, 1986). $\mathrm{BB}$ rats provide a congenital AVP KO model for endocrine studies. In adult rats, it is thought that ACTH release from the anterior pituitary is controlled mainly by $\mathrm{CRH}$, whereas AVP acts to support this effect. In rats, the first 2 weeks of postnatal life are termed the stress hyporesponsive period (SHRP), when the response of the HPA axis to stressful stimuli is greatly reduced. GC regulation of PVN CRH expression is not developed fully in the SHRP. On the contrary, PVN AVP regulation matures early and is functional during the SHRP and thus, AVP may have an important role in regulating ACTH production and release during the developmental SHRP. Studies using BB rats show that during the neonatal period AVP is crucial for the expression of ACTH stress responses, but neither AVP nor ACTH is required for the generation of cort stress responses. In contrast to adults, AVP seems to be the most important regulator of ACTH secretion during the early postnatal period.

In adult homozygous $\mathrm{BB}$ rats, basal pituitary $\mathrm{ACTH}$ concentration, as well as plasma ACTH and cort concentrations, appears to be normal. Following $10 \mathrm{~min}$ of forced swim, plasma ACTH and cort concentrations were virtually identical in AVP-deficient BB rats and controls.

However, $105 \mathrm{~min}$ following onset of the stressor, plasma cort concentrations were significantly elevated in BB AVP KO rats. Synthetic AVP delivered to the PVN, concomitantly with stressor exposure, resulted in normalized plasma cort concentrations. Thus, PVN AVP likely acts as a paracrine signal to facilitate the return of plasma cort to basal concentrations following acute stress exposure (Zelena et al, 2008).

In restraint stress experiments (daily, $60 \mathrm{~min}$ restraints) utilizing the $\mathrm{BB}$ rat as a model of AVP deficiency, normal $\mathrm{ACTH}$ and cort responses to acute restraint (initial $60 \mathrm{~min}$ restraint; no previous stress exposure) were observed. The fast ACTH response to the 11th and 15th restraints, but not the 5th or 8th restraint stress exposures, was significantly lower in male, but not in female, BB rats compared with controls (Zelena et al, 2004). These data suggest that either the changes in ACTH are not essential for the activation of the HPA axis under conditions of chronic stress or AVP deficiency is compensated for the other mediators.

\section{Oxytocin}

OT, a nine amino-acid peptide, is a neurohypophyseal hormone synthesized primarily in the hypothalamus. The majority of OT is produced in the magnocellular neurons of the PVN and supraoptic nuclei and is transported to the posterior lobe of the pituitary for storage and release into the periphery. OT is thought to be anxiolytic and have stressattenuating effects. Evidence suggests that OT and $\mathrm{CRH}$ have reciprocal effects. $\mathrm{CRH}$ stimulates both $\mathrm{ACTH}$ and OT release, but the mechanism by which these occur is different with differences in OT arising as a result of $\mathrm{CRH}$ directly or indirectly affecting magnocellular neurons in the PVN.

In response to stress, OT is released from the neurohypophyseal terminals into the blood, but also within specific brain nuclei including the PVN. The release of OT is dependent 
upon the condition and amplitude of the stressor and thus, OT may supplement the stress-induced HPA axis response. Below, we discuss OTKO mice as a genetic model of OT deletion to help define a role for OT in stress responsiveness.

Examination of PVN CRH mRNA in OTKO mice revealed similar to expression in wild-type mice under basal conditions. Response to psychogenic stress (exposure to platform shaker) resulted in an increase in anxiety-like behavior and plasma cort concentrations in OTKO female, but not in OTKO male mice, compared with wild-type mice. Unlike female OTKO mice, male OTKO and wild-type mice secreted the same amount of cort in response to psychogenic stress. These data suggest the heightened plasma cort concentrations in female, but not in male, OTKO mice in response to platform shaker stress, likely represents heightened HPA axis activity (Amico et al, 2008).

\section{POMC Deficiency}

POMC, as mentioned previously, is the precursor to ACTH. In POMC-null mice, ACTH levels are low and there is a deficiency in cort (Yaswen et al, 1999). Given that both CRH KO (Muglia et al, 1995) and GR KO pups die due to adrenal insufficiency, the viability of the POMC-null mice is believed to be influenced by maternal-released cort. This implies that ACTH is not necessary for an organism's survival if there is access to cort. Comparatively, there are human mutations in the $P O M C$ gene that prevent $P O M C$ translation or interfere with ACTH synthesis and result in POMC-deficient humans, who also have low ACTH levels and cort deficiency (Krude et al, 1998). The disruption of HPA axis activity through POMC deletion differentiates the role of ACTH and cort play in an organism's survival.

\section{ACTH Deficiency}

Isolated ACTH deficiency (IAD) is a disorder in humans characterized by a deficiency primarily in pituitary ACTH (Andrioli et al, 2006) (Steinberg et al, 1954). There are a number of causes of IAD including genetic mutations in pituitary genes. T-box pituitary-restricted transcription factor (TPIT) is a protein necessary for the transcription of POMC and the terminal differentiation of POMC cells specifically in the pituitary (Lamolet et al, 2001). Therefore when this transcription factor is deleted, a mouse model of IAD can be generated as described by Pulichino et al (2003). TPIT null mice have low ACTH and no detectable cort. In a subset of patients with neonatal onset IAD, loss of function mutations in TPIT have been identified. These patients have deficits in the levels of ACTH and cort secreted (Couture et al, 2012; Vallette-Kasic et al, 2005). Thus, genetic disruption of TPIT causes IAD and disrupts HPA axis activity in rodents and humans. The importance of transcription factors in HPA axis regulation is further delineated in the following section.

\section{Pituitary Transcription Factors}

The ability of CRH and AVP to induce ACTH secretion occurs, in part, through their activation of pituitary transcription factors that regulate POMC gene expression. Below, we describe the effects of disrupting these transcription factors on HPA axis activity.

Tpit, Pitx1, and Nur77. Tpit and Pitx are pituitary transcription factors involved in specific expression of POMC in pituitary corticotrophs and melanotrophs (Lamolet et al, 2001). CRH activates Tpit and Nur77 (member of the subfamily of orphan nuclear receptors) causing them to act on response elements on the POMC gene to induce POMC transcription (Kovalovsky et al, 2002; Maira et al, 2003). In vitro deletion or mutations of Tpit, Pitx, and $\mathrm{NuR}$ response elements abolishes both CRH-mediated activation and GCmediated inhibition of POMC.

PROP1. Another transcription factor, Prophet of Pit-1 gene (POMC) encodes a paired-like homeodomain protein and is expressed early in pituitary gland development and regulates cell differentiation (Araujo et al, 2013; Raetzman et al, 2004). Patients with pituitary corticotroph tumors express high levels of PROP1, which leads to increased expression of POMC and ACTH (Araujo et al, 2013). Conversely, inactivating mutations in PROP1 causes combined/multiple pituitary hormone deficiency (CPHD/MPHD) in humans and animals. The CPHD/MPHD disease leads to deficiencies in a number of pituitary hormones including $\mathrm{ACTH}$, growth hormone, follicle stimulating hormone, prolactin, and luteinizing hormone. In a study of patients with MPHD and a PROP 1 mutation $4 \%$ of them have a corticotrophs deficiency and a tendency for ACTH and cortisol deficiency with age (Vallette-Kasic et al, 2001). In a family with CPHD, $83 \%$ of the members over the age of 43 had ACTH/cortisol insufficiency. Low cortisol concentrations and unresponsive ACTH/cortisol to hypoglycemia due to PROP1 mutations and CPHD have been observed in a number of other studies (Asteria et al, 2000; Lamesch et al, 2002). In contrast to human studies, studies in PROP1-deficient mice demonstrate elevation in plasma ACTH and cort concentrations that are ore elevated with stress (Nasonkin et al, 2011). This difference in HPA axis activation between human and mice with a mutation in the same gene is very interesting. However, the cause of this difference remains unknown. One possible explanation could be that the PROP1 gene activated different transcriptional events in humans compared with mice, and this leads to opposite HPA axis activation. This information represents a precaution against using gene studies in rodents as absolute translation for what occurs in humans.

\section{Inflammatory Genes}

The majority of the genes discussed thus far have been directly associated with the HPA axis pathway. This section deviates into genes involved in the inflammatory system that 
have been shown to affect HPA axis activity. There is a very strong interaction between the neuroendocrine system and the immune/inflammatory system (Pace and Miller, 2009; Turnbull et al, 1999). Under basal conditions, low concentrations of GCs are necessary for normal immune and inflammatory function (Morand, 2000). In the event of chronic stress, activation of the HPA axis leads to a rise in GCs which act as immunosuppressors and antiinflammatory cytokines (Uchoa et al, 2014). Organisms experiencing chronic stress are at risk for infections and impaired wound healing (Godbout and Johnson, 2006). Alternatively, in the event of an immune or inflammatory challenge, increased pro-inflammatory cytokines can increase CRH and AVP secretion from the PVN and drive HPA axis to increase circulating GCs to negatively regulate the increase in cytokines (Chrousos, 1995). The bidirectional interplay between the stress and immune/inflammatory systems creates a regulatory feedback loop. This section evaluates the effects of disruption in a number of inflammation-related molecules on HPA axis activity.

Leukemia inhibitory factor. Leukemia inhibitory factor (LIF), a member of the IL-6 family of cytokines, is involved in facilitating cell differentiation (Shimazaki et al, 2001); thus, its disruption affects normal tissue and organ development. During an inflammatory challenge, LIF levels in the pituitary are dramatically increased and contribute to the HPA axis response to inflammation. Specific LIF overexpression in the pituitary using the glycoprotein hormone alpha-subunit causes pituitary corticotroph hyperplasia and results in a Cushingoid phenotype. Consequently, these pituitary LIF overexpressing mice display increased basal plasma cort concentrations and impaired dexamethasonemediated cort suppression. In another study, the growth hormone promoter was used to overexpress pituitary LIF in mice and led to impaired pituitary development. These mice displayed disruption in expression of a number of pituitary hormones, including an increase in ACTH mRNA levels. Plasma concentrations of cort were not measured in this study. These two studies demonstrate genes that affect pituitary development, and thus pituitary hormone levels can disrupt normal HPA axis activity. The targeting of LIF using different promoters likely accounts for the differences in mouse phenotype between the two studies. Also of note, LIF has been demonstrated to act in concert with CRH to induce POMC transcription and ACTH synthesis (Wang et al, 1996). Thus, elevation in ACTH and cort may not only be due to pituitary corticotroph hyperplasia but also LIF directly inducing ACTH secretion. In comparison, knocking out LIF in mice results in reduced plasma ACTH and cort levels (Chesnokova and Melmed, 2002). When LIF expression is suppressed by a cytokine-inducible inhibitor, Suppressor of Cytokine Signaling 3 (SOCS-3), ACTH levels are also suppressed (Auernhammer et al, 1998). Thus, increased pituitary SOCS-3 levels negatively regulate HPA axis activity and in LIF KO mice, decrease ACTH and cort.
STAT3 and SOCS-3. In vitro studies show that deletion of $\mathrm{CRH}$-responsive regions in the POMC gene decreases POMC transcription not only by CRH, but also by LIF (Ray et al, 1998). To identify LIF-responsive regions on the POMC gene, Bousquet et al (2000) performed 5'-deletions of the $P O M C$ promoter). The authors identified LIF-responsive regions that also contain DNA-binding motifs for signal transducer and activator of transcription 3 (STAT3) and determined that LIF-induced STAT3 activates POMC transcription by directly binding to its promoter. In addition, LIF-activated STAT3 indirectly mediates POMC transcription by activating cFOS and JunB that bind to the POMC AP-1 element. This identifies STAT3 as another regulator $P O M C$ gene transcription and thus HPA axis activation. Interestingly, LIF-induced STAT3 activation can also be disrupted by SOCS-3 overexpression, hence suppressing HPA axis activity (Bousquet et al, 2000). These data represent pathways through which inflammatory cytokines drive HPA axis activation, and their inhibitors drive its suppression. This indicates that the inflammatory system has a way to regulate HPA axis activity independent of psychological stress-induced HPA axis regulation.

Annexin 1 (Lipocortin 1). Annexin 1 (Lipocortin 1) is a calcium-dependent membrane binding protein that is increased by GCs to mediate GC anti-inflammatory actions (Perretti and D'Acquisto, 2009). It is highly expressed in the anterior pituitary and has a role in the inhibition of ACTH by GCs (Taylor et al, 1993). Annexin 1 null mice have a 4-fold increase specifically in corticotroph cells, which led to increased pituitary ACTH mRNA (Morris et al, 2006). However, plasma concentrations of ACTH and cort are not altered. Interestingly, the increase in pituitary ACTH was only observed in male Annexin 1 null mice, not in females, suggesting the possible influence of sex hormones in altering inflammation-mediated HPA axis activity (Hannon et al, 2003; Jankord et al, 2007; Spinedi et al, 1994).

Together, these data define a role for inflammatory cytokines in the regulation of pituitary HPA axis activity. While LIF and STAT3 are shown to increase HPA axis activity through action on pituitary corticotrophs, SOC-3 and Annexin 1 are shown to decrease HPA axis activity. There are undoubtedly other cytokines and inflammatory molecules activated in signaling pathways that may influence pituitary-driven HPA axis regulation. This represents a large area of research in delineating networks between inflammatory signaling pathways and the HPA axis.

\section{TRANSLATIONAL STUDIES}

HPA axis dysfunction has been linked to major depression in humans (Dale et al, 2015). Studies have investigated the role of polymorphisms mapped to genes involved in HPA axis regulation in the modulation of clinical features of major depression. Variability at genes encoding proteins with a pivotal role in HPA axis regulation have demonstrated the importance of polymorphisms mapped to genes involved in 
HPA axis function in the presentation of clinical features in major depressive patients.

The influence of genetic variants in CRHR1, CRHR2, CRH$\mathrm{BP}$, and FKBP5 genes have been investigated in both the risk for depression and antidepressant treatment response in humans (Papiol et al, 2007). A genetic variation in the CRHR1 gene, rs110402, was associated with an increased risk to present a seasonal pattern and an early age of onset of the first depressive episode. In the CRHR2 gene, allele G carriers of rs2270007 showed a worse overall response to certain antidepressant treatments (Papiol et al, 2007).

A principal function of increased $\mathrm{CRH}$ expression in human depression is demonstrated by both clinical and preclinical studies (Bartolomucci and Leopardi, 2009). In depression, elevated concentrations of $\mathrm{CRH}$ can be found in the cerebrospinal fluid (Lee et $a l, 2012$ ) and in the number of CRH expressing cells in the PVN (Raadsheer et al, 1994). On the contrary, a dulled ACTH response to CRH delivery has also been associated with depressive-like behavior (Heim et al, 2000). This restricted secretory response of ACTH to CRH is thought to be caused by elevated basal cort concentrations.

Other studies have investigated whether polymorphisms in $\mathrm{GR}$, or genes that are involved in regulating GR activity, including the human GR gene (NR3C1), CRH, $A V P$, and an additional five cochaperones of GR (BAG1, STUB1, TEBP, $F K B P 4$, and FKBP5), contribute to the susceptibility for developing depressive-like behavior and the responsiveness to antidepressant treatment. For example, a significant association was found in response to antidepressant treatment and the reoccurrence of depressive episodes with SNPs in FKBP5. This polymorphism was associated with an increased number of lifetime depressive episodes and a shorter duration in response to antidepressant treatment (Binder et al, 2004). These data suggest that genes involved in regulating GR sensitivity are also involved in the causality of depression and drug treatment response.

\section{FUTURE DIRECTIONS AND CLINICAL IMPLICATIONS}

The evaluation of genetic alterations that affect HPA axis activity discussed thus far paint a picture of the complexity of genes involved in the neuroendocrine system. Understanding the interaction between these genes and their individual function in stress regulation will help to elucidate their roles in coordinating stress responses.

Moreover, elucidating the complex relationship between gene products, neural circuits, the stress response and stressrelated disorders holds enormous potential to decipher the mechanisms involved and develop new therapies for psychiatric disorders.

Early-life environment can dramatically impact development of the HPA axis and future stress responsiveness. The knowledge surrounding the potential mechanisms by which early life environment can influence brain development and predispose individuals to psychiatric disorders later in life come from animal studies (Champagne et al, 2003; Pryce et al, 2005; Weaver et al, 2004). Some unanswered questions need to be addressed including particular brain regions that are most vulnerable to alteration, the impact of specific stressors, the neural mechanisms involved in programming persistent behavior, and the critical developmental periods that are the most susceptible suffering the greatest impact of early-life experience. Previous studies have been limited in their inability to selectively manipulate endogenous gene activity isolated to specific brain nuclei. Recent advances in research techniques and novel analytical methods will help to define the complex interactions between genes and the mechanisms involved in the pathophysiology of stressrelated disorders and may hold unique opportunities to answer these questions.

To help define the influence of modulators of the stress response in manifesting disease states, future studies in rodents should include additional regional-specific and temporal targeting strategies. Optogenetics is one promising new method for stress research that will allow for stimulation and inhibition of region-specific neurons will help determine the necessity of particular neurons in HPA axis activity (Tye and Deisseroth, 2012). The prospect of optogenetics research lies in the ability to help target specific brain nuclei and manipulate cell-specific neurons with high temporal accuracy.

In addition, CRISPR-mediated genome editing could offer significant clinical therapeutic potential by identifying particular genes involved in mediating dysregulated stress responsiveness in rodents (Mali et al, 2013). CRISPR is an innovative research tool that produces selective gene editing for effective manipulation of gene expression in the endogenous environment and overcomes some of the limitations of previous genome modifying methodologies. One benefit of CRIPR technology is that it can be applied to diverse species and extended to a wider range of species than was previously possible with more limited techniques. The use of CRISPR technology in diverse species will help to narrow the gap between well-established model organisms and emerging experimental species. In addition, future studies using CRISPR technology could be used to engineer specific variants in animal models to assess human polymorphisms found to be associated with altered stress responsiveness.

Previous studies in rodents have noted sex differences in HPA axis regulation. A number of studies have shown that GC levels are higher in females than in males following stress exposure in both humans and rodents (Dalla et al, 2005; Viau, 2002). These sex differences in HPA axis stress responsiveness could be due to sexual dimorphisms in brain functioning and circulating plasma cort concentrations. Other potential mechanisms involved in mediating the sexual dimorphism in HPA activity are gonadal steroids or sympathoadrenal stress axes acting together with the HPA axis to produce the variation found in males and females. Additional studies need to continue to explore the neurological underpinnings of this difference to better understand the underlying mechanisms that influence the association between gender differences and stress reactivity. Future 
research should be aimed at elucidating the regulatory mechanisms of HPA axis activity to provide a better understanding of the abnormal adaptations of neurobiological systems involved in the stress response. Innovative techniques that allow for molecular dissection of particular gene activity in specific brain regions will be critical in elucidating the mechanisms involved in mediating normal HPA axis activity and could potentially identify novel therapeutic strategies aimed at treating mental health disorders associated with HPA axis dysfunction.

Advances in human studies have permitted detailed analysis of genetic factors associated with individual differences for risk of developing a psychiatric disorder. New technologies allow for identification of individuals at greater risk for responding more slowly to treatment or experiencing more severe effects of mood disorders. These studies include identifying genetic polymorphisms in specific populations associated with a greater risk of developing psychiatric disorders.

Future translational studies will allow for personalized therapy based on pharmacogenomics. These studies will eventually lead to the development of selective treatment agents, targeted at specific tissues, to reduce the negative side effects associated with a less targeted treatment approach. For example, because GCs are a principal regulator of HPA axis activity, and HPA axis dysfunction has been associated with most mood disorders, there is great hope for the application of GC targeted therapies in treating mood disorders. However, because of the wide expression of GR in both the brain and the periphery, unwanted side effects are almost guaranteed. Selective treatments that target GR in specific regions could hold great promise for future therapeutic treatments. By establishing an association of particular polymorphisms with symptoms, individuals identified as being at greater risk for developing a mood disorder could receive preventive therapies or start treatments to lower their risk before development of symptoms.

Translational research approaches should include further identification of biomarkers associated with an increased risk for developing a mood disorder and targeted therapies based on an individualized treatment approach.

In summary, this review provides evidence for the role of receptors, neuroendocrine molecules, transcription factors, and inflammatory genes in modulating HPA axis activity. The diversity of genes that influence the HPA axis leads to organismal differences to the same stressor. The studies suggested in the future directions section will be important in providing better insight into neuropsychiatric consequences of HPA axis dysregulation.

\section{FUNDING AND DISCLOSURE}

The authors declare no conflict of interest.

\section{ACKNOWLEDGMENTS}

This work was supported in part by grant 1 R01 MH079010$01 \mathrm{~A} 2$ to LJ Muglia.

\section{REFERENCES}

Ambroggi F, Turiault M, Milet A, Deroche-Gamonet V, Parnaudeau S, Balado E et al (2009). Stress and addiction: glucocorticoid receptor in dopaminoceptive neurons facilitates cocaine seeking. Nat Neurosci 12: 247-249.

Amico JA, Cai HM, Vollmer RR (2008). Corticosterone release in oxytocin gene deletion mice following exposure to psychogenic versus non-psychogenic stress. Neurosci Lett 442: 262-266.

Anagnostis P, Athyros VG, Tziomalos K, Karagiannis A, Mikhailidis DP (2009). Clinical review: the pathogenetic role of cortisol in the metabolic syndrome: a hypothesis. J Clin Endocrinol Metab 94: 2692-2701.

Andrioli M, Pecori Giraldi F, Cavagnini F (2006). Isolated corticotrophin deficiency. Pituitary 9: 289-295.

Araujo RV, Chang CV, Cescato VA, Fragoso MC, Bronstein MD, Mendonca BB et al (2013). PROP1 overexpression in corticotrophinomas: evidence for the role of PROP1 in the maintenance of cells committed to corticotrophic differentiation. Clinics (Sao Paulo) 68: 887-891.

Asteria C, Oliveira JH, Abucham J, Beck-Peccoz P (2000). Central hypocortisolism as part of combined pituitary hormone deficiency due to mutations of PROP-1 gene. Eur J Endocrinol 143: 347-352.

Auernhammer CJ, Chesnokova V, Melmed S (1998). Leukemia inhibitory factor modulates interleukin- 1beta-induced activation of the hypothalamo-pituitaryadrenal axis. Endocrinology 139: 2201-2208.

Bale TL, Lee KF, Vale WW (2002). The role of corticotropin-releasing factor receptors in stress and anxiety. Integr Comp Biol 42: 552-555.

Balthasar N, Dalgaard LT, Lee CE, Yu J, Funahashi H, Williams T et al (2005). Divergence of melanocortin pathways in the control of food intake and energy expenditure. Cell 123: 493-505.

Bamberger CM, Schulte HM, Chrousos GP (1996). Molecular determinants of glucocorticoid receptor function and tissue sensitivity to glucocorticoids. Endocr Rev 17: 245-261.

Barik J, Marti F, Morel C, Fernandez SP, Lanteri C, Godeheu G et al (2013). Chronic stress triggers social aversion via glucocorticoid receptor in dopaminoceptive neurons. Science 339: 332-335.

Bartolomucci A, Leopardi R (2009). Stress and depression: preclinical research and clinical implications. PLoS One 4: e4265.

Berger S, Wolfer DP, Selbach O, Alter H, Erdmann G, Reichardt HM et al (2006). Loss of the limbic mineralocorticoid receptor impairs behavioral plasticity. Proc Natl Acad Sci USA 103: 195-200.

Binder EB, Salyakina D, Lichtner P, Wochnik GM, Ising M, Putz B et al (2004). Polymorphisms in FKBP5 are associated with increased recurrence of depressive episodes and rapid response to antidepressant treatment. Nat Genet 36: 1319-1325.

Bonfiglio JJ, Inda C, Refojo D, Holsboer F, Arzt E, Silberstein S (2011). The corticotropin-releasing hormone network and the hypothalamic-pituitaryadrenal axis: molecular and cellular mechanisms involved. Neuroendocrinology 94: 12-20.

Bousquet C, Zatelli MC, Melmed S (2000). Direct regulation of pituitary proopiomelanocortin by STAT3 provides a novel mechanism for immunoneuroendocrine interfacing. J Clin Invest 106: 1417-1425.

Boyle MP, Brewer JA, Funatsu M, Wozniak DF, Tsien JZ, Izumi Y et al (2005). Acquired deficit of forebrain glucocorticoid receptor produces depression-like changes in adrenal axis regulation and behavior. Proc Natl Acad Sci USA 102 473-478.

Boyle MP, Kolber BJ, Vogt SK, Wozniak DF, Muglia LJ (2006). Forebrain glucocorticoid receptors modulate anxiety-associated locomotor activation and adrenal responsiveness. J Neurosci 26: 1971-1978.

Brewer JA, Khor B, Vogt SK, Muglia LM, Fujiwara H, Haegele KE et al (2003). T-cell glucocorticoid receptor is required to suppress COX-2-mediated lethal immune activation. Nat Med 9: 1318-1322.

Champagne FA, Francis DD, Mar A, Meaney MJ (2003). Variations in maternal care in the rat as a mediating influence for the effects of environment on development. Physiol Behav 79: 359-371

Chesnokova V, Melmed S (2002). Minireview: neuro-immuno-endocrine modulation of the hypothalamic-pituitary-adrenal (HPA) axis by gp130 signaling molecules. Endocrinology 143: 1571-1574.

Chrousos GP (1995). The hypothalamic-pituitary-adrenal axis and immune-mediated inflammation. N Engl J Med 332: 1351-1362.

Couture C, Saveanu A, Barlier A, Carel JC, Fassnacht M, Fluck CE et al (2012). Phenotypic homogeneity and genotypic variability in a large series of congenital isolated ACTH-deficiency patients with TPIT gene mutations. J Clin Endocrinol Metab 97: E486-E495.

Dale E, Bang-Andersen B, Sanchez C (2015). Emerging mechanisms and treatments for depression beyond SSRIs and SNRIs. Biochem Pharmacol 95: 81-97. 
Dalla C, Antoniou K, Drossopoulou G, Xagoraris M, Kokras N, Sfikakis A et al (2005). Chronic mild stress impact: are females more vulnerable? Neuroscience 135: 703-714.

Dallman MF, Levin N, Cascio CS, Akana SF, Jacobson L, Kuhn RW (1989). Pharmacological evidence that the inhibition of diurnal adrenocorticotropin secretion by corticosteroids is mediated via type I corticosterone-preferring receptors. Endocrinology 124: 2844-2850.

Dallman MF, Strack AM, Akana SF, Bradbury MJ, Hanson ES, Scribner KA et al (1993). Feast and famine: critical role of glucocorticoids with insulin in daily energy flow. Front Neuroendocrinol 14: 303-347.

Dave-Sharma S, Wilson RC, Harbison MD, Newfield R, Azar MR, Krozowski ZS et al (1998). Examination of genotype and phenotype relationships in 14 patients with apparent mineralocorticoid excess. J Clin Endocrinol Metab 83: 2244-2254.

de Kloet ER, Van Acker SA, Sibug RM, Oitzl MS, Meijer OC, Rahmouni K et al (2000). Brain mineralocorticoid receptors and centrally regulated functions. Kidney Int 57: 1329-1336.

De Kloet ER, Vreugdenhil E, Oitzl MS, Joels M (1998). Brain corticosteroid receptor balance in health and disease. Endocr Rev 19: 269-301.

Dempster EL, Burcescu I, Wigg K, Kiss E, Baji I, Gadoros J et al (2007). Evidence of an association between the vasopressin $\mathrm{V} 1 \mathrm{~b}$ receptor gene (AVPR1B) and childhood-onset mood disorders. Arch Gen Psychiatry 64: 1189-1195.

Elkabes S, Loh YP, Nieburgs A, Wray S (1989). Prenatal ontogenesis of proopiomelanocortin in the mouse central nervous system and pituitary gland: an in situ hybridization and immunocytochemical study. Brain Res Dev Brain Res 46: 85-95.

Fries GR, Vasconcelos-Moreno MP, Gubert C, dos Santos BT, Sartori J, Eisele B et al (2014). Hypothalamic-pituitary-adrenal axis dysfunction and illness progression in bipolar disorder. Int J Neuropsychopharmacol 18.

Gathercole LL, Stewart PM (2010). Targeting the pre-receptor metabolism of cortisol as a novel therapy in obesity and diabetes. J Steroid Biochem Mol Biol 122: 21-27.

Godbout JP, Johnson RW (2006). Age and neuroinflammation: a lifetime of psychoneuroimmune consequences. Neurol Clin 24: 521-538.

Gomez-Sanchez EP (2011). Mineralocorticoid receptors in the brain and cardiovascular regulation: minority rule? Trends Endocrinol Metab 22: 179-187.

Hannon R, Croxtall JD, Getting SJ, Roviezzo F, Yona S, Paul-Clark MJ et al (2003). Aberrant inflammation and resistance to glucocorticoids in annexin 1-/- mouse. FASEB J 17: 253-255.

Harris AP, Holmes MC, de Kloet ER, Chapman KE, Seckl JR (2013). Mineralocorticoid and glucocorticoid receptor balance in control of HPA axis and behaviour. Psychoneuroendocrinology 38: 648-658.

Heim C, Newport DJ, Heit S, Graham YP, Wilcox M, Bonsall R et al (2000). Pituitaryadrenal and autonomic responses to stress in women after sexual and physical abuse in childhood. JAMA 284: 592-597.

Herman JP (2013). Neural control of chronic stress adaptation. Front Behav Neurosci 7: 61

Herman JP, McKlveen JM, Solomon MB, Carvalho-Netto E, Myers B (2012). Neural regulation of the stress response: glucocorticoid feedback mechanisms. Braz $J$ Med Biol Res 45: 292-298.

Hindelang C, Felix JM, Laurent FM, Klein MJ, Stoeckel ME (1990). Ontogenesis of proopiomelanocortin gene expression and regulation in the rat pituitary intermediate lobe. Mol Cell Endocrinol 70: 225-235.

Ivell R, Schmale H, Krisch B, Nahke P, Richter D (1986). Expression of a mutant vasopressin gene: differential polyadenylation and read-through of the mRNA $3^{\prime}$ end in a frame-shift mutant. EMBO J 5: 971-977.

Jacobson L, Muglia LJ, Weninger SC, Pacak K, Majzoub JA (2000). CRH deficiency impairs but does not block pituitary-adrenal responses to diverse stressors. Neuroendocrinology 71: 79-87.

Jacobson L, Sapolsky R (1991). The role of the hippocampus in feedback regulation of the hypothalamic- pituitary-adrenocortical axis. Endocr Rev 12: 118-134.

Jankord R, Turk JR, Schadt JC, Casati J, Ganjam VK, Price EM et al (2007). Sex difference in link between interleukin-6 and stress. Endocrinology 148: 3758-3764.

Keck ME, Kern N, Erhardt A, Unschuld PG, Ising M, Salyakina D et al (2008). Combined effects of exonic polymorphisms in CRHR1 and AVPR1B genes in a case/control study for panic disorder. Am J Med Genet B Neuropsychiatr Genet 147B: 1196-1204.

Keen-Rhinehart E, Michopoulos V, Toufexis DJ, Martin El, Nair H, Ressler KJ et al (2009). Continuous expression of corticotropin-releasing factor in the central nucleus of the amygdala emulates the dysregulation of the stress and reproductive axes. Mol Psychiatry 14: 37-50.

Kinlein SA, Wilson CD, Karatsoreos IN (2015). Dysregulated hypothalamic-pituitaryadrenal axis function contributes to altered endocrine and neurobehavioral responses to acute stress. Front Psychiatry 6: 31.
Kolber BJ, Boyle MP, Wieczorek L, Kelley CL, Onwuzurike CC, Nettles SA et al (2010). Transient early-life forebrain corticotropin-releasing hormone elevation causes long-lasting anxiogenic and despair-like changes in mice. J Neurosci 30: 2571-2581.

Kolber BJ, Roberts MS, Howell MP, Wozniak DF, Sands MS, Muglia LJ (2008). Central amygdala glucocorticoid receptor action promotes fear-associated $\mathrm{CRH}$ activation and conditioning. Proc Natl Acad Sci USA 105: 12004-12009.

Kotelevtsev Y, Brown RW, Fleming S, Kenyon C, Edwards CR, Seckl JR et al (1999). Hypertension in mice lacking 11 beta-hydroxysteroid dehydrogenase type 2. J Clin Invest 103: 683-689.

Kovalovsky D, Refojo D, Liberman AC, Hochbaum D, Pereda MP, Coso OA et al (2002). Activation and induction of NUR77/NURR1 in corticotrophs by $\mathrm{CRH}$ / CAMP: involvement of calcium, protein kinase A, and MAPK pathways. $\mathrm{Mol}$ Endocrinol 16: 1638-1651.

Krude H, Biebermann H, Luck W, Horn R, Brabant G, Gruters A (1998). Severe early-onset obesity, adrenal insufficiency and red hair pigmentation caused by POMC mutations in humans. Nat Genet 19: 155-157.

Kwak SP, Morano MI, Young EA, Watson SJ, Akil H (1993). Diurnal CRH mRNA rhythm in the hypothalamus: decreased expression in the evening is not dependent on endogenous glucocorticoids. Neuroendocrinology 57: 96-105.

Lamesch C, Neumann S, Pfaffle R, Kiess W, Paschke R (2002). Adrenocorticotrope deficiency with clinical evidence for late onset in combined pituitary hormone deficiency caused by a homozygous 301-302 delAG mutation of the PROP1 gene. Pituitary 5: 163-168.

Lamolet B, Pulichino AM, Lamonerie T, Gauthier Y, Brue T, Enjalbert A et al (2001). A pituitary cell- restricted $\mathrm{T}$ box factor, Tpit, activates POMC transcription in cooperation with Pitx homeoproteins. Cell 104: 849-859.

Laryea G, Arnett MG, Muglia LJ (2012). Behavioral studies and genetic alterations in corticotropin-releasing hormone $(\mathrm{CRH})$ neurocircuitry: insights into human psychiatric disorders. Behav Sci (Basel) 2: 135-171.

Laryea G, Schutz G, Muglia LJ (2013). Disrupting hypothalamic glucocorticoid receptors causes HPA axis hyperactivity and excess adiposity. Mol Endocrinol 27: 1655-1665.

Lee RJ, Hempel J, Tenharmsel A, Liu T, Mathe AA, Klock A (2012). The neuroendocrinology of childhood trauma in personality disorder. Psychoneuroendocrinology 37: 78-86.

Leszczynska-Rodziewicz A, Szczepankiewicz A, Dmitrzak-Weglarz M, Skibinska M, Hauser J (2012). Association between functional polymorphism of the AVPR1b gene and polymorphism rs1293651 of the CRHR1 gene and bipolar disorder with psychotic features. J Affect Disord 138: 490-493.

Leszczynska-Rodziewicz A, Szczepankiewicz A, Pawlak J, Dmitrzak-Weglarz M, Hauser J (2013). Association, haplotype, and gene-gene interactions of the HPA axis genes with suicidal behaviour in affective disorders. ScientificWorldJournal 2013: 207361

Lovenberg TW, Liaw CW, Grigoriadis DE, Clevenger W, Chalmers DT, De Souza EB et al (1995). Cloning and characterization of a functionally distinct corticotropinreleasing factor receptor subtype from rat brain. Proc Natl Acad Sci USA 92: 836-840.

Maira M, Couture C, Le Martelot G, Pulichino AM, Bilodeau S, Drouin J (2003). The T-box factor Tpit recruits SRC/p160 co-activators and mediates hormone action. J Biol Chem 278: 46523-46532.

Mali P, Aach J, Stranges PB, Esvelt KM, Moosburner M, Kosuri S et al (2013). CAS9 transcriptional activators for target specificity screening and paired nickases for cooperative genome engineering. Nat Biotechnol 31: 833-838.

McEwen BS, Stellar E (1993). Stress and the individual. Mechanisms leading to disease. Arch Intern Med. 153: 2093-2101.

McKlveen JM, Myers B, Flak JN, Bundzikova J, Solomon MB, Seroogy KB et al (2013). Role of prefrontal cortex glucocorticoid receptors in stress and emotion. Biol Psychiatry 74: 672-679.

Morand EF (2000). Corticosteroids in the treatment of rheumatologic diseases. Curr Opin Rheumatol 12: 171-177.

Morris JF, Omer S, Davies E, Wang E, John C, Afzal T et al (2006). Lack of annexin 1 results in an increase in corticotroph number in male but not female mice. J Neuroendocrinol 18: 835-846.

Muglia L, Jacobson L, Dikkes P, Majzoub JA (1995). Corticotropin-releasing hormone deficiency reveals major fetal but not adult glucocorticoid need. Nature 373: $427-432$

Muglia LJ, Jacobson L, Luedke C, Vogt SK, Schaefer ML, Dikkes P et al (2000). Corticotropin-releasing hormone links pituitary adrenocorticotropin gene expression and release during adrenal insufficiency. J Clin Invest 105: 1269-1277.

Muglia LJ, Jacobson L, Weninger SC, Luedke CE, Bae DS, Jeong KH et al (1997). Impaired diurnal adrenal rhythmicity restored by constant infusion of corticotropinreleasing hormone in corticotropin-releasing hormone-deficient mice. J Clin Invest 99: 2923-2929. 
Nasonkin IO, Ward RD, Bavers DL, Beuschlein F, Mortensen AH, Keegan CE et al (2011). Aged PROP1 deficient dwarf mice maintain ACTH production. PLoS One 6: e28355.

Naughton M, Dinan TG, Scott LV (2014). Corticotropin-releasing hormone and the hypothalamic- pituitary-adrenal axis in psychiatric disease. Handb Clin Neurol 124: 69-91.

Pace TW, Miller AH (2009). Cytokines and glucocorticoid receptor signaling. Relevance to major depression. Ann NY Acad Sci 1179: 86-105.

Pape HC (2005). GABAergic neurons: gate masters of the amygdala, mastered by dopamine. Neuron 48: 877-879.

Papiol S, Arias B, Gasto C, Gutierrez B, Catalan R, Fananas L (2007). Genetic variability at HPA axis in major depression and clinical response to antidepressant treatment. J Affect Disord 104: 83-90.

Perretti M, D'Acquisto F (2009). Annexin A1 and glucocorticoids as effectors of the resolution of inflammation. Nat Rev Immunol 9: 62-70.

Pryce CR, Ruedi-Bettschen D, Dettling AC, Weston A, Russig H, Ferger B et al (2005). Long-term effects of early-life environmental manipulations in rodents and primates: Potential animal models in depression research. Neurosci Biobehav Rev 29: 649-674.

Pulichino AM, Vallette-Kasic S, Tsai JP, Couture C, Gauthier Y, Drouin J (2003). Tpit determines alternate fates during pituitary cell differentiation. Genes Dev 17: 738-747.

Raadsheer FC, Hoogendijk WJ, Stam FC, Tilders FJ, Swaab DF (1994). Increased numbers of corticotropin- releasing hormone expressing neurons in the hypothalamic paraventricular nucleus of depressed patients. Neuroendocrinology 60: 436-444

Raetzman LT, Ross SA, Cook S, Dunwoodie SL, Camper SA, Thomas PQ (2004). Developmental regulation of Notch signaling genes in the embryonic pituitary: Prop1 deficiency affects Notch2 expression. Dev Biol 265: 329-340.

Ray DW, Ren SG, Melmed S (1998). Leukemia inhibitory factor regulates proopiomelanocortin transcription. Ann NY Acad Sci 840: 162-173.

Regev L, Neufeld-Cohen A, Tsoory M, Kuperman Y, Getselter D, Gil S et al (2011). Prolonged and site- specific over-expression of corticotropin-releasing factor reveals differential roles for extended amygdala nuclei in emotional regulation. $\mathrm{Mol}$ Psychiatry 16: 714-728.

Regev L, Tsoory M, Gil S, Chen A (2012). Site-specific genetic manipulation of amygdala corticotropin- releasing factor reveals its imperative role in mediating behavioral response to challenge. Biol Psychiatry 71: 317-326.

Reul JM, de Kloet ER (1985). Two receptor systems for corticosterone in rat brain: microdistribution and differential occupation. Endocrinology 117: 2505-2511.

Reul JM, Gesing A, Droste S, Stec IS, Weber A, Bachmann C et al (2000). The brain mineralocorticoid receptor: greedy for ligand, mysterious in function. Eur $J$ Pharmacol 405: 235-249.

Rozeboom AM, Akil H, Seasholtz AF (2007). Mineralocorticoid receptor overexpression in forebrain decreases anxiety-like behavior and alters the stress response in mice. Proc Natl Acad Sci USA 104: 4688-4693.

Schmidt MV, Sterlemann V, Wagner K, Niederleitner B, Ganea K, Liebl C et al (2009). Postnatal glucocorticoid excess due to pituitary glucocorticoid receptor deficiency: differential short- and long- term consequences. Endocrinology 150: 2709-2716.

Scott LV, Dinan TG (1998). Vasopressin and the regulation of hypothalamic-pituitaryadrenal axis function: implications for the pathophysiology of depression. Life Sci 62: 1985-1998.

Selye H (1936). A syndrome produced by diverse nocuous agents. 1936. Natue 138: 3479.

Seney ML, Sibille E (2014). Sex differences in mood disorders: perspectives from humans and rodent models. Biol Sex Differ 5: 17.

Shimazaki T, Shingo T, Weiss S (2001). The ciliary neurotrophic factor/leukemia inhibitory factor/gp130 receptor complex operates in the maintenance of mammalian forebrain neural stem cells. J Neurosci 21: 7642-7653.

Smith GW, Aubry JM, Dellu F, Contarino A, Bilezikjian LM, Gold LH et al (1998). Corticotropin releasing factor receptor 1-deficient mice display decreased anxiety, impaired stress response, and aberrant neuroendocrine development. Neuron 20: 1093-1102.

Solomon MB, Furay AR, Jones K, Packard AE, Packard BA, Wulsin AC et al (2012). Deletion of forebrain glucocorticoid receptors impairs neuroendocrine stress responses and induces depression-like behavior in males but not females. Neuroscience 203: 135-143.

Spinedi E, Salas M, Chisari A, Perone M, Carino M, Gaillard RC (1994). Sex differences in the hypothalamo-pituitary-adrenal axis response to inflammaton and neuroendocrine stressors. Evidence for a pituitary defect in the autoimmune disease-susceptible female Lewis rat. Neuroendocrinology 60: 609-617.

Steinberg A, Shechter FR, Segal HI (1954). True pituitary Addison's disease, a pituitary unitropic deficiency; fifteen-year follow-up. J Clin Endocrinol Metab 14 1519-1529.

Tanoue A, Ito S, Honda K, Oshikawa S, Kitagawa Y, Koshimizu TA et al (2004). The vasopressin $\mathrm{V} 1 \mathrm{~b}$ receptor critically regulates hypothalamic-pituitary-adrenal axis activity under both stress and resting conditions. J Clin Invest 113: 302-309.

Taylor AD, Cowell AM, Flower J, Buckingham JC (1993). Lipocortin 1 mediates an early inhibitory action of glucocorticoids on the secretion of ACTH by the rat anterior pituitary gland in vitro. Neuroendocrinology 58: 430-439.

Tronche F, Kellendonk C, Kretz O, Gass P, Anlag K, Orban PC et al (1999). Disruption of the glucocorticoid receptor gene in the nervous system results in reduced anxiety. Nat Genet 23: 99-103.

Turnbull AV, Smith GW, Lee S, Vale WW, Lee KF, Rivier C (1999). CRF type I receptor-deficient mice exhibit a pronounced pituitary-adrenal response to local inflammation. Endocrinology 140: 1013-1017.

Tye KM, Deisseroth K (2012). Optogenetic investigation of neural circuits underlying brain disease in animal models. Nat Rev Neurosci 13: 251-266.

Uchoa ET, Aguilera G, Herman JP, Fiedler JL, Deak T, de Sousa MBC (2014). Novel aspects of glucocorticoid actions. J Neuroendocrinol 26 557-572.

Vallette-Kasic S, Barlier A, Teinturier C, Diaz A, Manavela M, Berthezene F et al (2001). PROP1 gene screening in patients with multiple pituitary hormone deficiency reveals two sites of hypermutability and a high incidence of corticotroph deficiency. J Clin Endocrinol Metab 86: 4529-4535.

Vallette-Kasic S, Brue T, Pulichino AM, Gueydan M, Barlier A, David M et al (2005). Congenital isolated adrenocorticotropin deficiency: an underestimated cause of neonatal death, explained by TPIT gene mutations. J Clin Endocrinol Metab 90 1323-1331.

van West D, Del-Favero J, Aulchenko Y, Oswald P, Souery D, Forsgren T et al (2004). A major SNP haplotype of the arginine vasopressin 1B receptor protects against recurrent major depression. Mol Psychiatry 9: 287-292.

Viau V (2002). Functional cross-talk between the hypothalamic-pituitary-gonadal and -adrenal axes. J Neuroendocrinol 14: 506-513.

Vincent MY, Jacobson L (2014). Glucocorticoid receptor deletion from the dorsal raphe nucleus of mice reduces dysphoria-like behavior and impairs hypothalamic-pituitary-adrenocortical axis feedback inhibition. Eur J Neurosci 39: 1671-1681

Wang Z, Ren SG, Melmed S (1996). Hypothalamic and pituitary leukemia inhibitory factor gene expression in vivo: a novel endotoxin-inducible neuro-endocrine interface. Endocrinology 137: 2947-2953.

Weaver IC, Cervoni N, Champagne FA, D'Alessio AC, Sharma S, Seckl JR et al (2004). Epigenetic programming by maternal behavior. Nat Neurosci 7: 847-854.

Wilson JD (1992). Williams Textbook of Endocrinology. W.B. Saunders: Philadelphia

Yaswen L, Diehl N, Brennan MB, Hochgeschwender U (1999). Obesity in the mouse model of pro- opiomelanocortin deficiency responds to peripheral melanocortin. Nat Med 5: 1066-1070.

Zelena D, Domokos A, Barna I, Mergl Z, Haller J, Makara GB (2008). Control of the hypothalamo- pituitary-adrenal axis in the neonatal period: adrenocorticotropin and corticosterone stress responses dissociate in vasopressin-deficient brattleboro rats. Endocrinology 149: 2576-2583.

Zelena D, Foldes A, Mergl Z, Barna I, Kovacs KJ, Makara GB (2004). Effects of repeated restraint stress on hypothalamo-pituitary-adrenocortical function in vasopressin deficient Brattleboro rats. Brain Res Bull 63: 521-530. 